\title{
Arc-parallel compression in the NW Himalaya: Evidence from structural and palaeostress studies of brittle deformation from the clasts of the Upper Siwalik, Uttarakhand, India
}

\author{
Dripta Dutta, Tuhin Biswas and Soumyajit MukherJeE* \\ Department of Earth Sciences, Indian Institute of Technology Bombay, Powai, Mumbai, \\ Maharashtra 400 076, India. \\ *Corresponding author.e-mail: soumyajitm@gmail.com
}

MS received 13 February 2018; revised 9 November 2018; accepted 29 November 2018; published online 8 May 2019

The sub-Himalayan Upper Siwalik rocks, between the Main Boundary Thrust (MBT) to the north and the Main Frontal Thrust (MFT) to the south, are intensely brittle sheared and jointed. Our field studies around Dehradun (India) furnished at least eight small-scale brittle slip directions, viz., r top-to-SW/SSW (up), top-to-SW/SSW (down), top-to-NE/NNE (up), top-to-NE/ENE (down), topto-NW (down), top-to-SE/SSE (up), top-to-SE/SSE (down) and top-to-NW/NNW (up). Additionally, we report near-vertical faults, four sets of joints (inclined: $\mathrm{J}_{1}$ and $\mathrm{J}_{2}$; near-vertical: $\mathrm{J}_{1 \mathrm{~V}}$ and $\mathrm{J}_{2 \mathrm{~V}}$ ). Palaeostress analyses using T-TECTO Studio X5 with all joint sets reveal two compression directions $\sim$ ENE-WSW and $\sim$ NNW-SSE. We propose two possible temporal relations between the joint sets: (i) $J_{1}, J_{2}, J_{1 V}$ and $\mathrm{J}_{2 \mathrm{~V}}$ are coeval ( $\sim \mathrm{ENE}-\mathrm{WSW}$ compression) and (ii) $\mathrm{J}_{1 \mathrm{~V}}$ and $\mathrm{J}_{2 \mathrm{~V}}$ developed coevally ( $\sim$ ENE-WSW compression) followed by $\mathrm{J}_{1}$ and $\mathrm{J}_{2}(\sim \mathrm{NNW}-\mathrm{SSE}$ compression), because arc-parallel compression (if any) occurs later than arc-perpendicular compression. The presence of already well-known strike-slip faults, viz., the Yamuna tear fault and the Ganga tear fault, at high angles, $\sim 55^{\circ}$ and $\sim 85^{\circ}$ to the orogenic trend, implies a possible arc-parallel compression in the Siwalik Himalaya in the study area. This NNW-SSE compression could also indicate a localised stress reorientation due to the curvature of the Thrust planes, viz., the MFT and the Asan Thrust (as observed in plan view) close to the study area. This study further shows that arc-parallel compression need not be restricted to the inner arc of an orogen, and/or, as in the case of the Himalaya, near the syntaxes.

Keywords. Arc-parallel compression; palaeostress; joints; Siwalik Himalaya.

\section{Introduction}

Arc-parallel extension has been well recorded from different segments of the Himalaya (e.g., Coleman 1996; Zhang et al. 2000; Murphy and Copeland
2005; Jessup et al. 2008; Jessup and Cottle 2010; Hintersberger et al 2010; Langille et al. 2010; Saylor et al. 2010; Styron et al. 2011; Xu et al. 2013; Nagy et al. 2015). Comparatively, reports on arc-parallel compression from the Himalaya

Supplementary material pertaining to this article is available on the Journal of Earth System Science website (http://www. ias.ac.in/Journals/Journal_of_Earth_System_Science). 
are less (e.g., Zeitler 1985; Treloar et al. 1991; Llana-Fúnez et al. 2006; Shah et al. 2011; Khan et al. 2014; Banerjee et al. 2015; Sayab et al. 2016). Interestingly, such compression has also been reported from other collisional orogens, e.g., the Indo-Myanmar range (Parameswaran and Rajendran 2016), the Alps (Peresson and Decker 1997), the Andes (Boutelier and Oncken 2010; Johnston et al. 2013), the Apennine (Carosi et al. 2002; Viti et al. 2004; Bonini et al. 2011), the Cascadia (Wang and He 1999), the Hellenic Arc (Konstantinou et al. 2006) and the Variscan (Johnston et al. 2013; Weil Viti et al. 2013).

Few models explain arc-parallel compression in terms of simultaneous compression and micro-plate rotation (Apennine; Viti et al. 2004), cessation of subduction retreat (Alps; Peresson and Decker 1997), lower flexural rigidity of downgoing lithosphere and/or high interplate friction (Andes; Boutelier and Oncken 2010), curved subduction zone (Hellenides; Durand et al. 2014 and references therein) and an orthogonal switch in the stress field (Variscan; Johnston et al. 2013; Del Greco et al. 2016). The Himalayan arc-parallel compression can be an outcome of either (i) strain concentration at the NW and the NE bends of the Himalayan thrusts (close to the syntaxes) (Treloar et al. 1991; Seeber and Pêcher 1998) or (ii) an increase in plate obliquity coupled with an increase in the arc-parallel shear away from the central Himalaya and towards the syntaxes, due to the India-Asia convergence (Khan et al. 2014). Moreover, Upton et al. (2008) suggested that oblique ramps can also cause a rotation of the principal stress axes. Hence, the possibility of an oblique ramp-induced arc-parallel compression in the Himalayan fold and thrust belt cannot be overlooked.

Brittle structural palaeostress analyses, which could be important to understand arc-parallel compression/extension in orogens, from outcrops can explain the shallow-crustal tectonics of terrains (Hancock 1985; Hancock et al. 1987; Eidelman and Reches 1992; Hippolyte 2001 and references therein). Clay, sand and conglomerate layers can sometimes act as markers for the syntectonic deformation (Hippolyte 2001). However, a lack of prominent slip indicators and marker horizons within sandy material/clay in sedimentary terrains can render brittle deformation indeterminate. Nevertheless, conglomerates can possess prominent signatures of brittle deformation in the form of striations, joints and slip especially within their clasts (Hippolyte 2001), which should be paid due attention.

Some discrepancies in the definition of faults and joints exist in geological literature (Mandl 2005). A joint can be extensional or shear with a negligible or notable slip on a micro-scale, which is invisible to the naked eye (Hancock 1985). This work designates 'joints' for those discontinuities that do not show any detectable displacement on the hand-specimen scale, whereas for any wall-parallel displacement, the term 'fault' is used.

This study describes and interprets the smallscale brittle structures in the clasts of the Upper Siwalik, observed mostly in (sub-) vertical sections. The faults and joints are usually limited to the clasts/pebbles and the surrounding sandy matrices. Sheared/jointed clasts have been previously studied from the Upper Siwalik (Rautela and Sati 1996; Srivastava and John 1999). However, none of the previous authors had analysed palaeostress from those clasts comprehensively. The aim of this paper is to investigate the stress conditions responsible for the geneses of the joints and faults in the Himalayan context. We first document these joints and faults by fieldwork. This is followed by palaeostress analyses using the T-TECTO Studio X5 software (Žalohar and Vrabec 2010). Finally, the palaeostress results have been explained in the regional tectonic context.

\section{Geology}

The $\sim$ NW trending Himalaya in the Indian sector is one of the youngest orogens in the world. The onset of collision between the Indian and the Eurasian plates has been found to be within 60-55 Ma (Copley et al. 2010; van Hinsbergen et al. 2011; White and Lister 2012; Chatterjee et al. 2013; Jagoutz et al. 2015; Hu et al. 2016 and references therein; Najman et al. 2017). However, some of the previous researchers, namely Garzanti et al. (1987), Rowley (1996), Guillot et al. (2003) and DeCelles et al. (2004), proposed the range $\sim 55-50 \mathrm{Ma}$ for the same. Collisional crustal thickening happened mainly by in-sequence SW-vergent thrusting. Towards the south, these are the Main Central Thrust (MCT) (25-0.7 Ma), the Main Boundary Thrust (MBT; 11-9 Ma) and the Main Frontal Thrust (MFT) $(<2.5 \mathrm{Ma}$; review in Mukherjee 2015). Stratigraphically, the Himalaya consists of (from north towards 

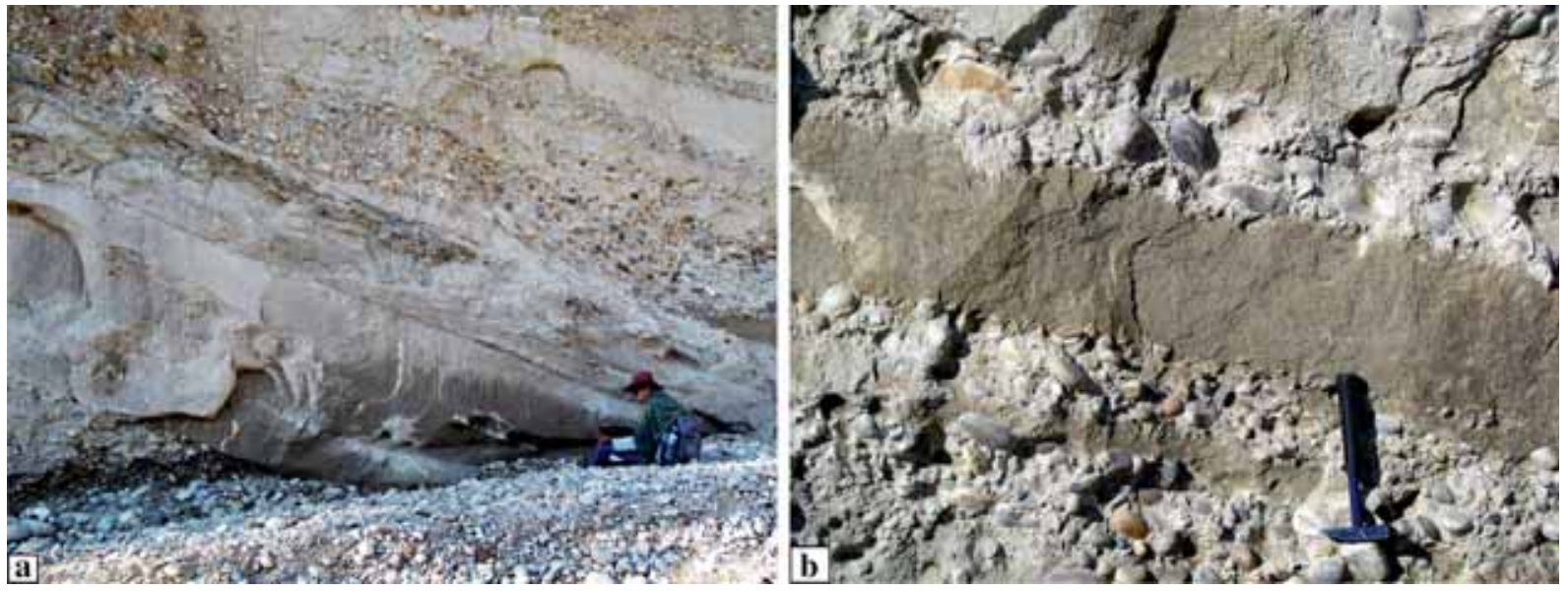

Figure 1. (a and b) Conglomerate-sandstone intercalations, Upper Siwalik Subgroup: The thickness of the sandstone or conglomerate horizons is inconsistent along the exposed sections. The litho-contacts are rarely curved or undulating. The sandstone layers contain thin isolated bands of conglomerate at places. Length of waist to head of D Dutta in $(\mathbf{a}) \sim 80 \mathrm{~cm}$, length of the hammer in $(\mathbf{b}) \sim 36 \mathrm{~cm}$.

south): (i) the Tethyan Himalayan Sequence (THS; 1840-40 Ma), (ii) the Greater Himalayan Crystalline (GHC; 1800-480 Ma), (iii) the Lesser Himalayan Sequence (LHS; 1870-520 Ma) (Mandal et al. 2015 and references therein) and (iv) the Siwalik range: $\sim 23-2 \mathrm{Ma}$ (Yin 2006 and references therein).

The Siwalik foreland basin developed as the subducting Indian plate flexed under the large tremendous crustal load of the uprising Himalaya (Lavé and Avouac 2000; Kumar et al. 2003; Valdiya 2016). Overall, the Siwalik Group (>7000 m thick) represents a coarsening upward non-marine succession. The mudstone-sand dominated Lower Siwalik Subgroup (Middle Miocene) is overlain by the sandstone-rich Middle Siwalik Subgroup (Late Miocene), followed by the conglomerate-sandstone dominated Upper Siwalik Subgroup (Plioceneearly Pleistocene) at the top (figure 1) (Dubey 2014; Goswami and Deopa 2018 and references therein). This study was conducted in the Boulder Conglomerate Formation of the Upper Siwalik Subgroup (figure 2), north of the $\sim 80-\mathrm{km}$-long Mohand range, Uttarakhand, India. In and around Mohand, this formation mostly dips gently $\left(30^{\circ}\right)$ towards the NE. The dip amount increases $\left(55-65^{\circ}\right)$ close to the MBT (Thakur et al. 2007).

From the MFT towards the north and up to the MBT, three significant thrust planes exist, viz., the Asan Thrust (AT), the Bhauwala Thrust (BT) and the Santaurgarh Thrust (ST). Jayangondaperumal et al. (2018) have reported the BT and the ST as active faults. The Siwalik rocks, which lie between the MFT and the MBT, are folded into the Mohand anticline, the Dun syncline and the Santaurgarh anticline (Wesnousky et al. 1999; Thakur and Pandey 2004). The Mohand anticline is a fault bend fold, developed on the MFT hanging wall (Thakur et al. 2007) showing a normal drag (Mukherjee 2012, 2014). The back-limb of the Mohand anticline dips gently towards NE and the steeper forelimb towards the SW. The MFT gradually becomes sub-horizontal towards the north at sub-surface (Suppe 1983). A similar interpretation comes from the Nepal Himalaya as well (Lavé and Avouac 2000).

In contrast, based on microstructural studies and dislocation modelling, Srivastava et al. (2016, 2018) recognise the Mohand anticline as a faultpropagation fold. The authors further state that the deformation intensity diminishes away along the axial trace of the anticline, i.e., towards the northwest and southeast. Eight strike-slip faults are also present: E1 (NNE-SSW trending) and E2 (N-S trending) developed due to the NE-SW compression, followed by the Ganga Tear Fault (GTF; NE-SW trending) and the Yamuna Tear Fault (YTF; NNE-SSW trending) that formed later due to an E-W compression, along with the NE-SW trending S1, S2 and S3 (Jayangondaperumal et al. 2010 and references therein). The rivers Ganga and Yamuna follow the trends of the GTF and YTF, respectively (figure 2). In 1956-1957, an exploratory well drilled over the Mohand anticline up to $\sim 5260 \mathrm{~m}$ depth by the Oil and Natural Gas Corporation Limited encountered the $\sim 700 \mathrm{~m}$ thick pre-tertiary Vindhyan rocks at $\sim 4600 \mathrm{~m}$ depth (Karunakaran and Rao 1976; Powers et al. 1998). 

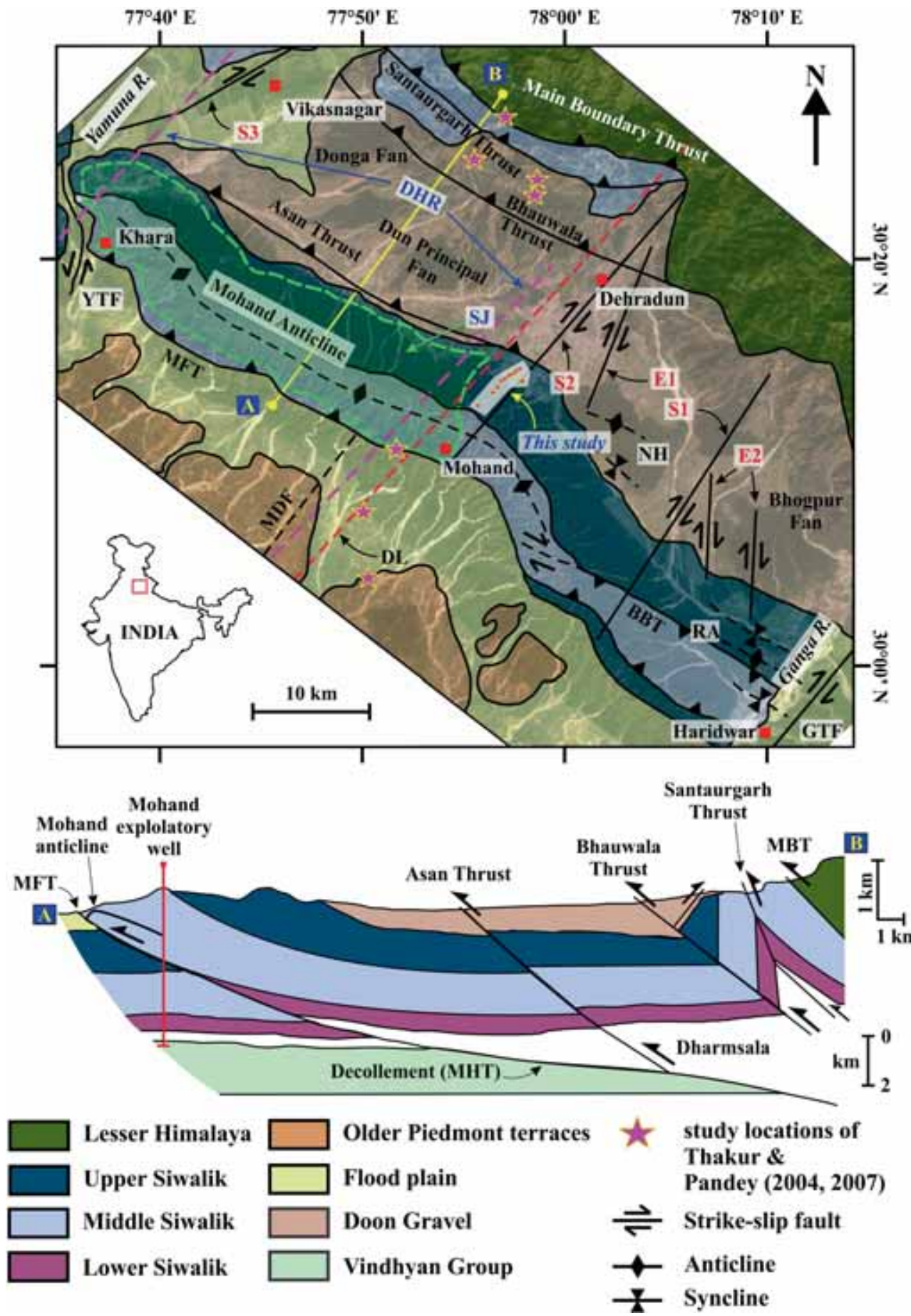

Figure 2. Geological map and cross-section of the study area after Thakur (2013). Map superposed over the Google Earth image. Study locations of Srivastava and John (1999), Thakur and Pandey (2004) and Thakur et al. (2007) are shown. E1, E2: early formed strike-slip faults. S1-S3: late strike-slip faults (Jayangondaperumal et al. 2010). SJ: study area of Srivastava and John (1999), MHT: Main Himalayan Thrust, MFT: Main Frontal Thrust, MBT: Main Boundary Thrust, BBT: Bhimgoda Back Thrust, YTF: Yamuna Tear Fault, GTF: Ganga Tear Fault, DHR: Delhi-Haridwar Ridge (blue arrows indicate the lateral extremities of the DHR); DL: Dehradun Lineament (Godin et al. 2018); MDF: Mahendragarh-Dehradun Fault (Sandhu et al. 2017); RA: Raiwala Anticline, NH: Nagsidh Hill (Jayangondaperumal et al. 2010).

Eighteen exploration wells were drilled by the ONGC between 1957 and 1990, only one of which (Jwalamukhi-I 1957) showed the presence of a shallow gas reservoir (in the Siwalik), the Lower
Siwalik sandstones being the potential reservoirs. In comparison, the number of exploration wells (56) and producing wells (47) in the Siwalik Group of Pakistan are much higher (Craig et al. 2018). 
Recent seismic studies show that the Vindhyan sediments thin gradually over a distance of $\sim 200 \mathrm{~km}$ NW from the Mohand exploratory well towards the Kangra recess (Prasad et al. 2011). Moreover, a $\sim 2-5 \mathrm{~km}$ thick sedimentary succession lies underneath the Siwalik Himalaya that increases towards the Indo-Gangetic plain. In the case of an earthquake, such a thick sedimentary pile can cause amplification

of the generated S-waves, rendering the region susceptible to seismicity (Borah et al. 2015).

\section{Field observations}

Fieldwork was carried out on a stretch of $\sim 4 \mathrm{~km}$ along the NE-SW trending Mohand-Rao River and its tributaries (figure 2). Deformed clasts, made up mainly of quartzites, sandstones, carbonates and cherts belonging to the Boulder Conglomerate Formation (Nanda 2002; Thakur et al. 2007) give conspicuous evidences of brittle slip. Joints are distinct within the clasts and often are obscure within the softer matrix. Sometimes joints continue from one clast into another (figure 3). No specific correlation exists between the dip amounts of the joints/faults and their location with respect to the hinge of the Mohand anticline. The intensely deformed zone thins out as it approaches towards the Middle Siwalik Subgroup to the south and towards the Dun Gravel to the north.

\subsection{Joints}

Joints are dominantly planar and sometimes curvi-planar. We report four joint sets (figure $4 \mathrm{a}$ and b): (i) NW-SE $\left(\mathrm{J}_{1}\right)$, (ii) $\sim \mathrm{E}-\mathrm{W}\left(\mathrm{J}_{2}\right)$, (iii) $\mathrm{NE}-\mathrm{SW}\left(\mathrm{J}_{1 \mathrm{~V}}\right)$ and (iv) ESE-WNW $\left(\mathrm{J}_{2 \mathrm{~V}}\right)$. Joint sets $\mathrm{J}_{1}$ and $\mathrm{J}_{2}$ (supplementary table $\mathrm{S} 1$ ) are the inclined ones with $\leq 60^{\circ}$ dip, whereas $\mathrm{J}_{1 \mathrm{~V}}$ and $\mathrm{J}_{2 V}$ (supplementary table S2) are near-vertical with $>80^{\circ}$ dip. No cross-cut relations between the joints were seen in the field. As far as the origin/nature of the joints is concerned, extension seems to be the cause given the I-shaped geometry of most of the joints (Hancock 1985). However, they could also be regarded as shear or hybrid joints, based on their parallelism with the nearby fault planes (section 3.2; both inclined and near-vertical ones) (Hancock 1985). Moreover, Mandl (2005) indicates that shear joints usually develop in conjugate sets, which has not been observed in this study. Also, tensional joints usually break around pebbles of conglomerates, whereas only shear joints can cut across pebbles and matrices. This happens in an unconsolidated matrix (Billings 2008). Hence, the geneses of these joints could not be deciphered accurately in this study.

\subsection{Faults}

Tectonic faults defined by slipped pebbles and semi-consolidated sandstones exhibit various shear senses. Eight fault slip senses (figure 4c) exist: top-to-SW/SSW down $\left(\mathrm{F}_{1}\right)$ (figure 5a), top-to-SW/ $\mathrm{SSW}$ up $\left(\mathrm{F}_{2}\right)$ (figure $5 \mathrm{~b}$ ), top-to-NE/NNE up $\left(\mathrm{F}_{3}\right)$ (figure 6a), top-to-NE/ENE down $\left(\mathrm{F}_{4}\right)$ (figure $6 \mathrm{~b}$ ), top-to-NW up $\left(\mathrm{F}_{5}\right)$ (figure $7 \mathrm{a}$ ), top-to-NW/NNW down $\left(\mathrm{F}_{6}\right)$ (figure $7 \mathrm{~b}$ ), top-to-SE/SSE up $\left(\mathrm{F}_{7}\right)$ (figure 8a) and top-to-SE/SSE down $\left(\mathrm{F}_{8}\right)$ (figure 8b) (see p. 157 of Passchier and Trouw (2015) for brittle shear nomenclatures). Cross-cut relations between the faults were not encountered in the field. Several NE and ESE trending nearvertical faults also exist in the field (supplementary tables S3 and S4). The following criteria are used to identify faults and shear senses.

1. Slip within clast: Millimetre-scale displacement within the clasts are seen (figure 7a; Hippolyte 2001). Several clasts that are cut by nearvertical brittle planes sometimes show relative movement in response to their broken counterparts. The faults are classified based on their trends into the following two types: (A) NE-SW faults $\left(\mathrm{F}_{1 \mathrm{~V}}\right)$ : these faults show only block movement with different slip senses (figure 9) and (B) WNW-ESE faults $\left(\mathrm{F}_{2 \mathrm{~V}}\right)$ : these faults demonstrate a major sinistral component apart from block movement (figure 10).

2. $Y$ - and P-brittle shear planes: These planes develop within clasts (figure 5a). The usually curved P-planes merge with rather straight sub-parallel Y-planes. Even in the absence of any slipped marker layers, such $\mathrm{Y}$ - and P-planes have been used convincingly to identify brittle slips (Passchier and Trouw 2015; Mukherjee 2007, 2010a, b, 2013a, b, c; Mukherjee and Koyi 2010a, b).

3. Displacement of marker planes: Softer clayey materials inside the harder sandy matrix sometimes act as marker layers, which possess a colour contrast to the matrix (figure 5b).

The majority of the inclined fault planes are $\sim N W-$ SE trending (66\%). The rest show a 

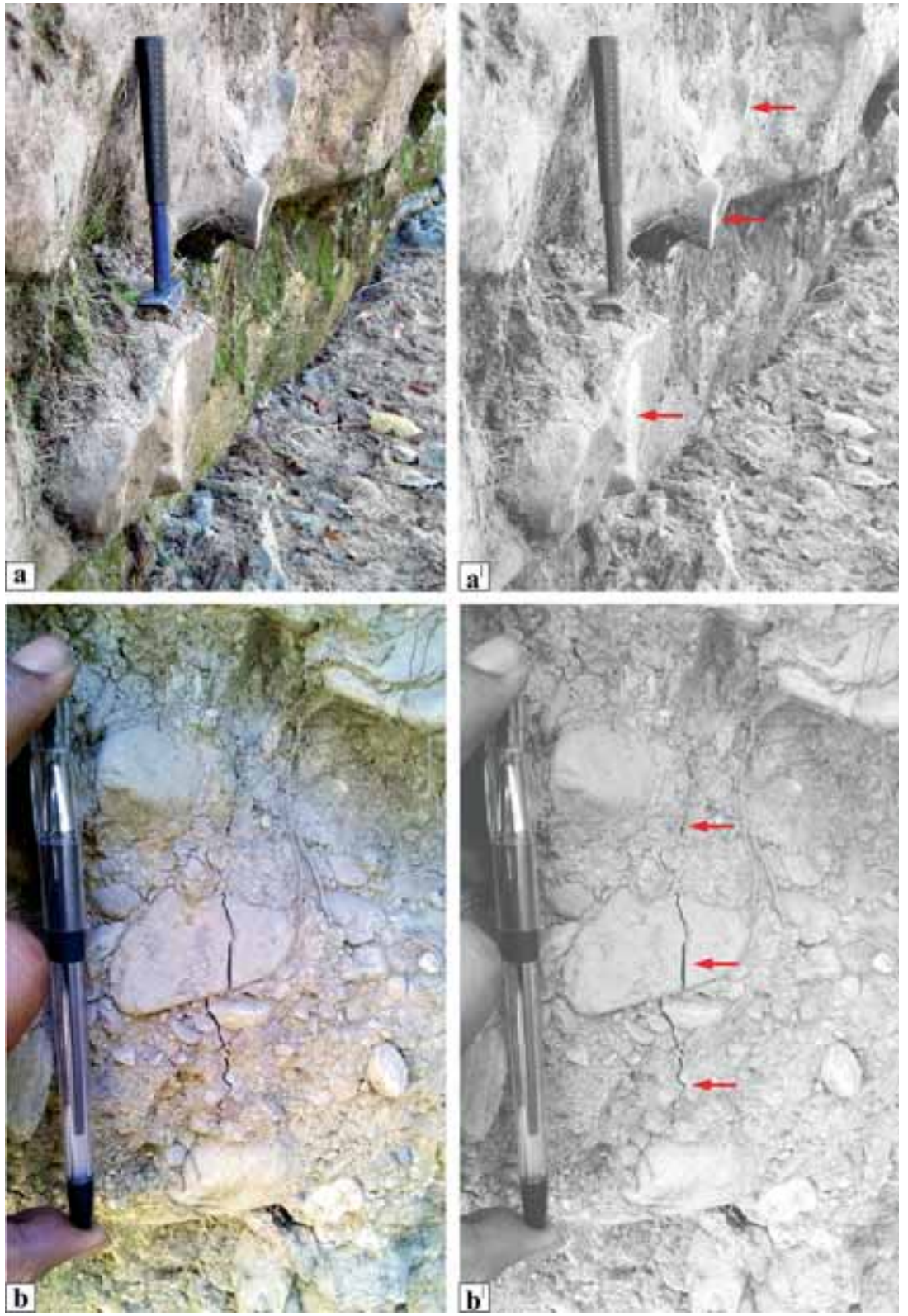

Figure 3. (a) Multiple clasts affected by near-vertical joints $\left(\mathrm{J}_{1 \mathrm{~V}}\right)$. Red arrows: joint surfaces. (b) Joint passing through the clast and the matrix. Length of the hammer in (a): $\sim 36 \mathrm{~cm}$ and the pen in (b): $\sim 14 \mathrm{~cm}$.

dominantly $\sim \mathrm{NE}-\mathrm{SW}$ trend. A non-tectonic origin of the slip planes would have shown a haphazard distribution instead. Moreover, the reader could be tempted to label these slips as gravity faults. But one must recollect that gravity/slump faults are usually listric (Conybeare 1979; Farrell 1984; Petersen et al. 1992; Baudon and Cartwright 2008 and references therein). In this study, however, listric faults are seldom observed. Also, such listric faults are mostly sub-vertical (figure 2 of Mazzini et al. 2003; Zhang et al. 2008; figure 5 of MacDonald et al. 2012). However, we observed gently dipping slip planes as well.

\section{Palaeostress analyses}

\subsection{Theory and background}

Palaeostress analyses determine the stress tensors that can justify multiple slip directions documented from field studies from a terrain (Tranos 2018 and references therein). This method, referred to as the stress inversion method, is now a wellestablished approach and has been widely used to date (e.g., Angelier 1984, 1989, 1990; Marrett and Allmendinger 1990; Delvaux and Sperner 2003; Žalohar and Vrabec 2008; Tranos 2012; Misra 

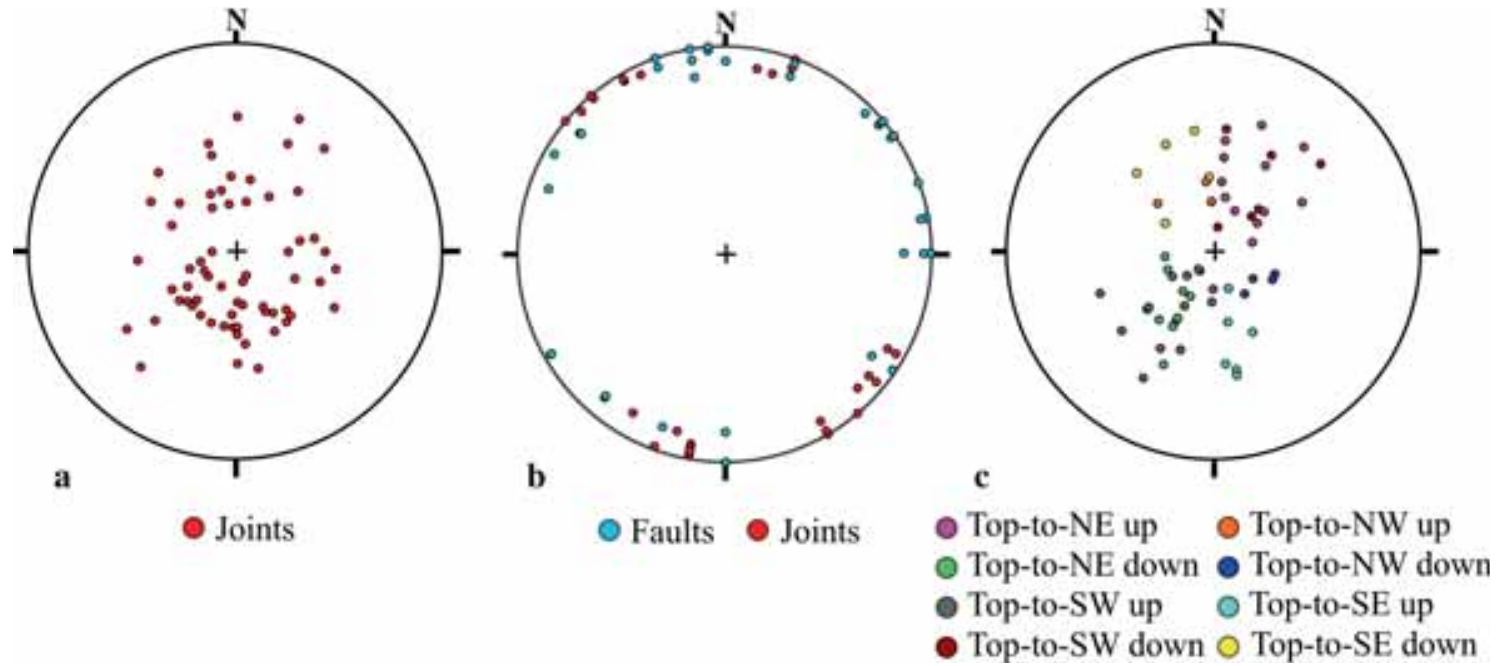

Figure 4. Stereo-plots of the poles of $(\mathbf{a})$ inclined joints $\left(\mathrm{J}_{1}\right.$ and $\left.\mathrm{J}_{2}\right),(\mathbf{b})$ near-vertical faults $\left(\mathrm{F}_{1 \mathrm{~V}}\right.$ and $\left.\mathrm{F}_{2 \mathrm{~V}}\right)$ and joints $\left(\mathrm{J}_{1 \mathrm{~V}}\right.$ and $\left.\mathrm{J}_{2 \mathrm{~V}}\right)$ and $(\mathbf{c})$ inclined faults $\left(\mathrm{F}_{1}-\mathrm{F}_{8}\right)$.
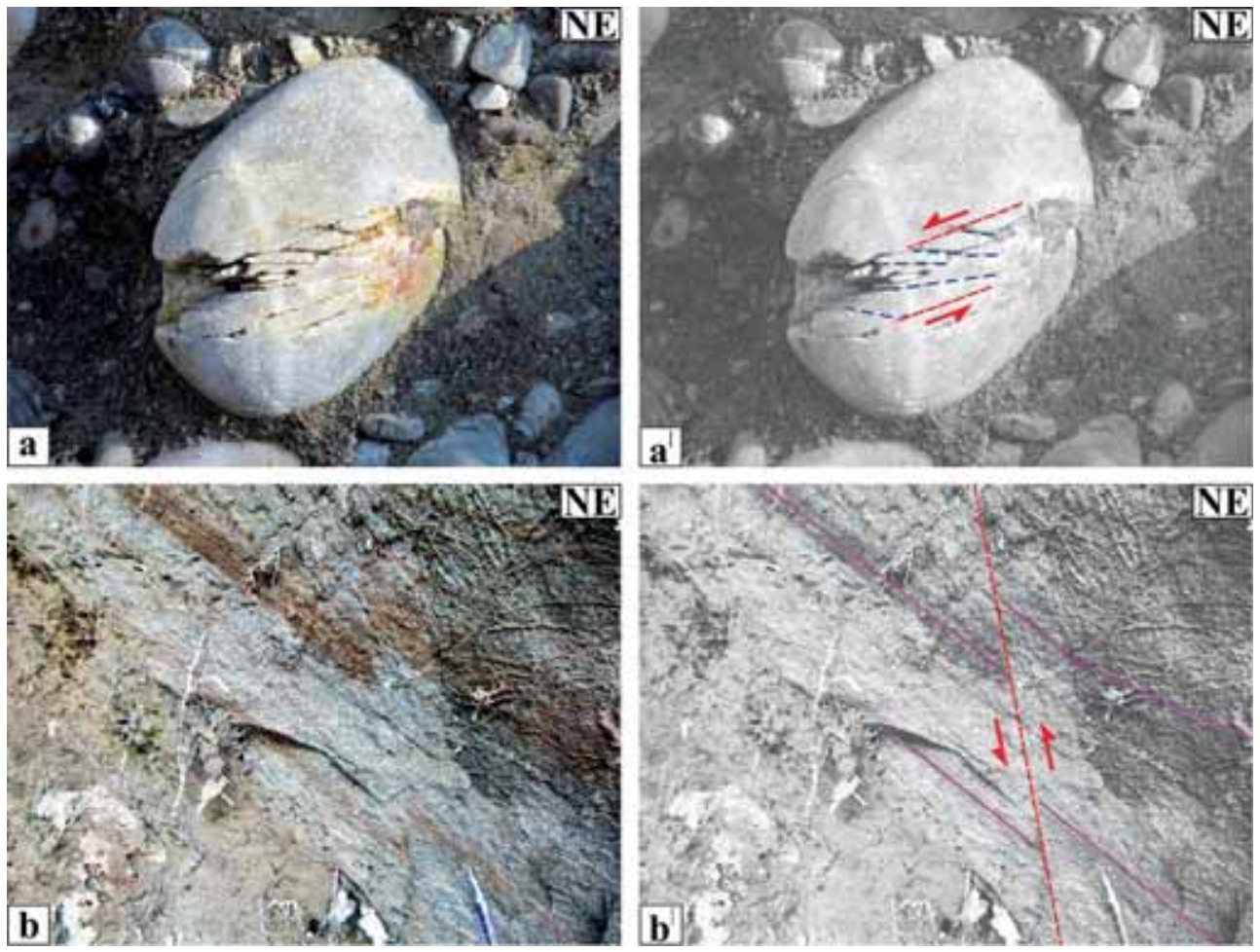

Figure 5. Brittle shear indicators: (a) top-to-SW down slipped sandstone clast. Red and blue dotted lines: Y- and the P-planes, respectively (width of view: $20 \mathrm{~cm}$ ) and (b) top-to-SW up shear within sandstone revealed by slipped marker (pink lines). Red dotted line: steeply dipping fault plane. Pen length in (b) $\sim 6 \mathrm{~cm}$.

et al. 2014; Shan and Liang 2015) though some difference in its various approaches exist (Simón in press). Palaeostress analyses follow a few assumptions (Wallace 1951; Bott 1959; Lisle 1988; Angelier 1989; Nemcok and Lisle 1995; Twiss and Unruh 1998; Nemcok et al. 1999; Yamaji et al. 2006; Žalohar and Vrabec 2007; Kaven et al. 2011;
Tranos 2015; Žalohar 2018): (i) slip direction along the fault plane parallels the direction of the resolved shear stress of the stress tensor, (ii) slips on separate fault planes are mutually independent, (iii) stresses that induced slip are homogeneous regionally, (iv) rotational faults and curved brittle planes (e.g., Mukherjee and Khonsari 2017) 

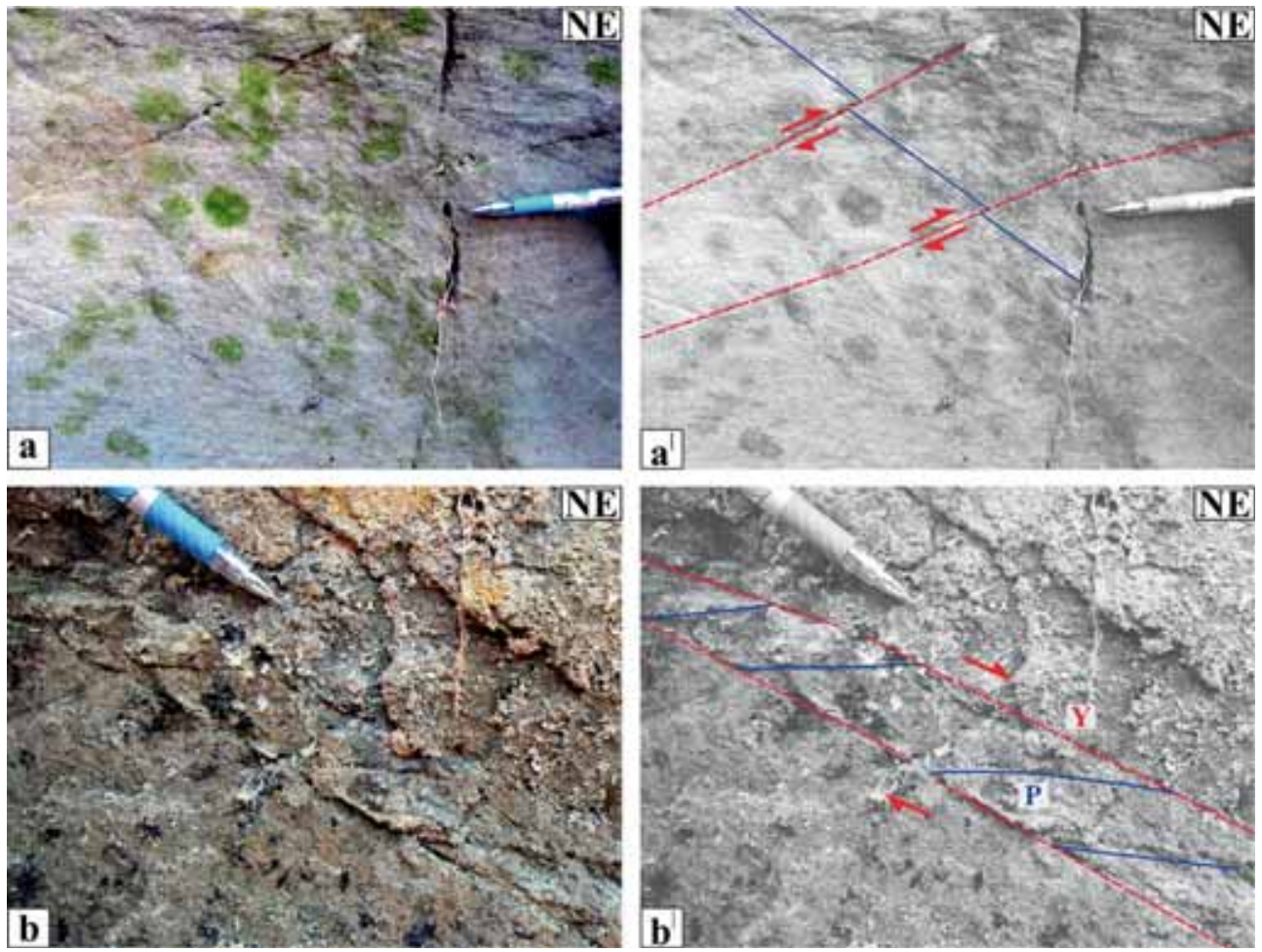

Figure 6. Brittle shear planes: (a) displaced veinlets (blue lines) within sandstone: top-to-NE up slip. Red dotted lines: fault planes and (b) top-to-NE down slip: Y- and P-planes marked with red and blue lines, respectively. Pen length: $\sim 10 \mathrm{~cm}$.
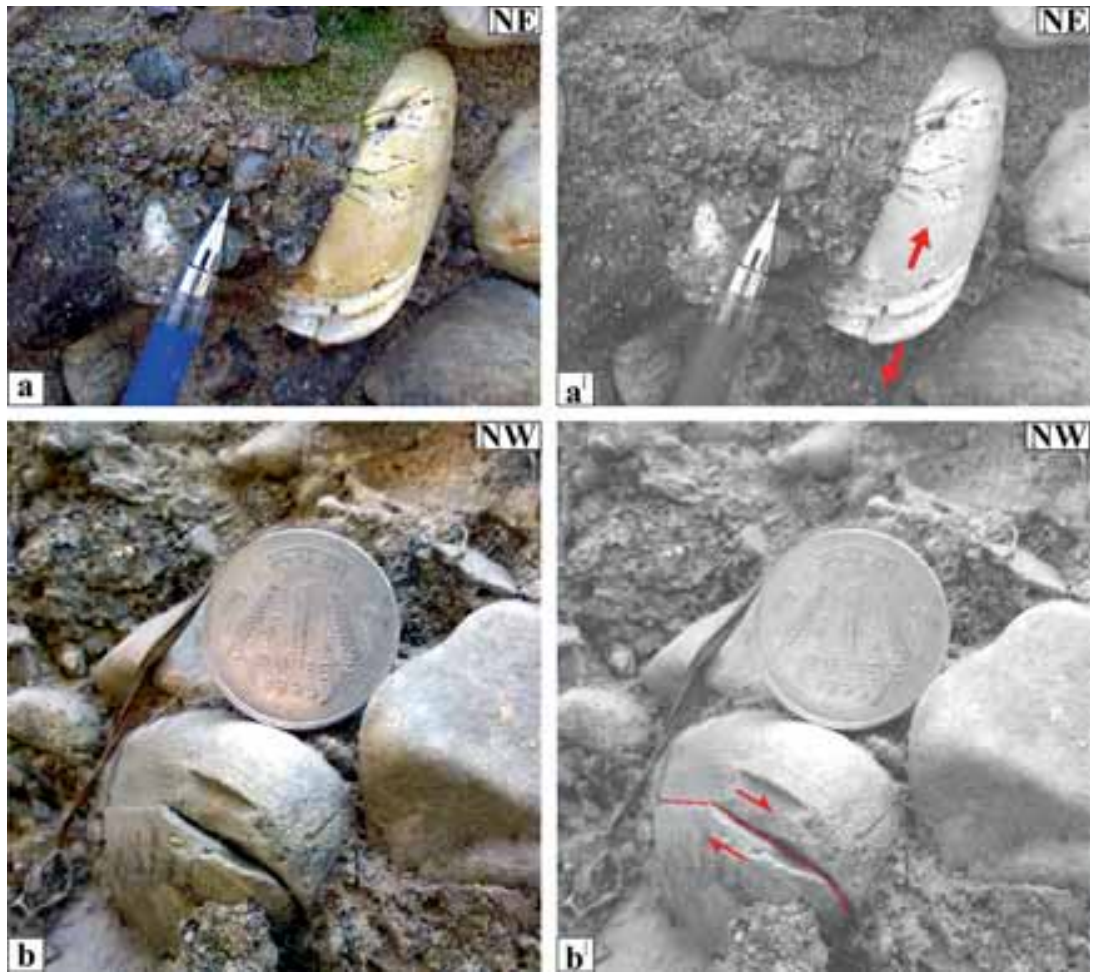

Figure 7. Top-to-NW up and top-to-NW down shear: (a) multiple fault planes inside a single clast. Pen length in (a): $\sim 6 \mathrm{~cm}$. Diameter of the coin in (b): $2 \mathrm{~cm}$.

are exempted and (v) the result of palaeostress inversion should comply with Amonton's law of friction.
The detailed method of stress inversion is beyond the scope of this paper and can be found elsewhere (e.g., Armijo et al. 1982; Angelier 1984; 

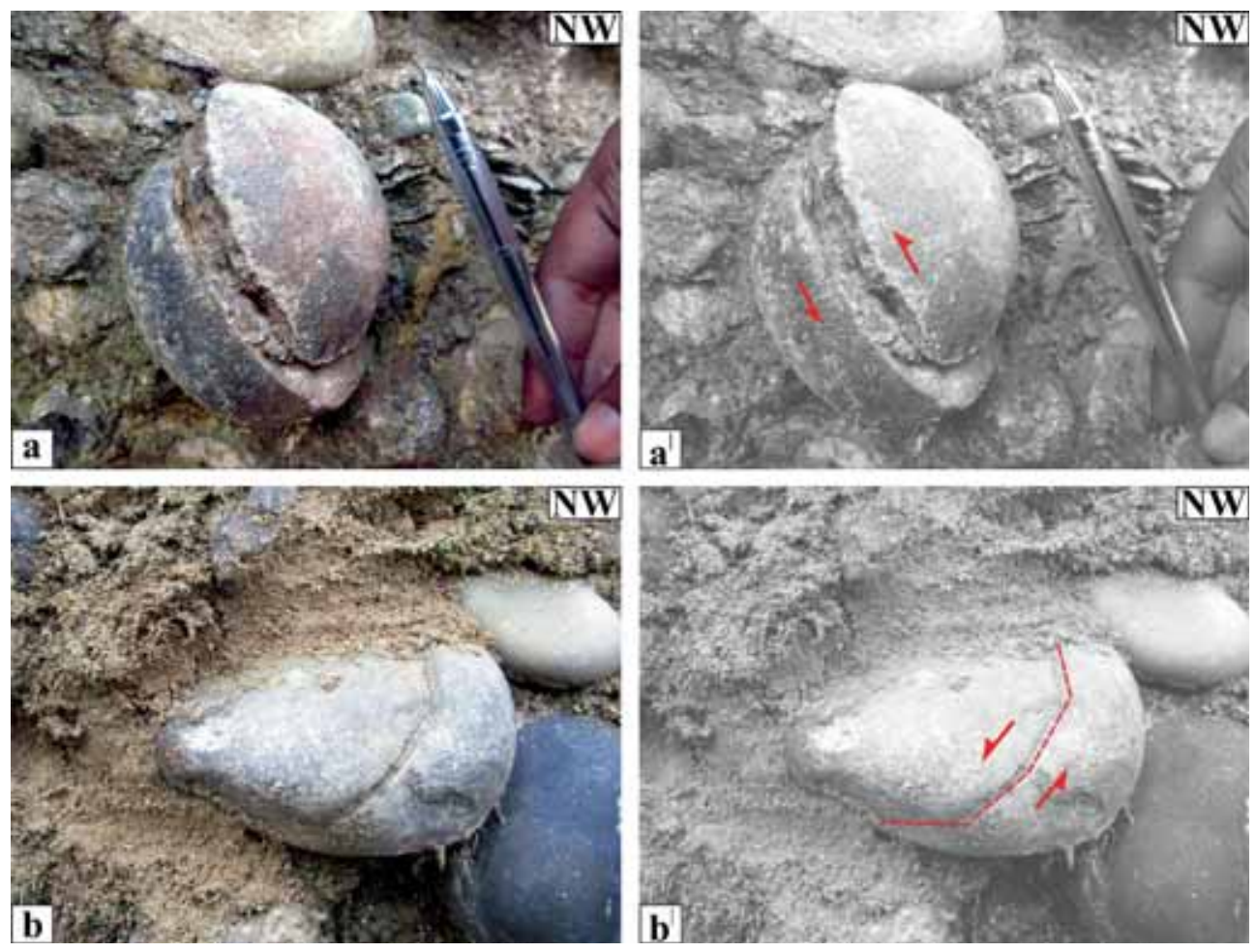

Figure 8. (a) Top-to-SE up shear in sandstone clast (Biswas and Dutta 2016) and (b) top-to-SE down shear (width of view: $15 \mathrm{~cm})$. Pen length in $(\mathrm{a}): \sim 14 \mathrm{~cm}$.

Yamaji 2000). In brief, the direction of net slips on a fault plane, revealed physically by the slickenlines, depends on the orientation of maximum shear stress. It is possible to deduce the relative magnitudes and the directions of the principal stresses, if the attitudes of faults are known along with the corresponding attitudes of net slip.

The T-TECTO software version X5 (author: J. Žalohar), established using the Gaussian method (Žalohar and Vrabec 2007), estimates the orientations of the principal stress axes and the stress ratio. This program provides both the geometric approach in the Right Dihedra Method (RDM; Angelier and Mechler 1977) and the statistical approach in the Visualisation of the Gauss Function Method (the VGF method: Žalohar and Vrabec 2007). The RDM gives the approximate orientation of the principal stresses. On the other hand, the VGF calculates the most probable orientation of the maximum $\left(\sigma_{1}\right)$ and the minimum $\left(\sigma_{3}\right)$ principal stresses for a set of faults active under a common stress condition. The optimum orientations of $\sigma_{1}$ and $\sigma_{3}$ for each fault are governed by the Coulomb-Mohr failure criterion (detail at Žalohar and Vrabec 2007). The VGF can utilise all kinds of joints and faults, whereas the RDM works only with faults.

\subsection{Method}

We analyse palaeostress using T-TECTO Studio $\mathrm{X} 5$ based on the joint data collected from the field. Total 100 joint planes: 66 inclined and 34 near-vertical (supplementary tables S1 and S2), are used. Since slickenlines were rarely observed in the field, fault-slip data are avoided and hence the VGF method has been utilised. Estimation of the stress tensor by this method requires the following inputs from the user: (i) 'Type': T or E (extensional fractures, mode I), F (shear fractures, mode II and III), or J (joints; different from the 'J-joint': van der Pluijm and Marshak 2004), (ii) 'azimuth' or the dip direction and (iii) 'dip' amount of the joint plane. The 'type' is chosen to be ' $\mathrm{J}$ ' for all the joints in the analyses. In T-TECTO Studio X5, for 'type' $\mathrm{T}$ or $\mathrm{E}, \sigma_{1}$ lies on the fracture plane and $\sigma_{3}$ is perpendicular to the fracture. For shear fractures $(\mathrm{F})$ and joints $(\mathrm{J}), \sigma_{1}$ is oblique to the fracture and $\sigma_{3}$ lies perpendicular to $\sigma_{1}$. Initially, the dominant joint sets $\left(\mathrm{J}_{1}: \sim \mathrm{NW}-\mathrm{SE}, \mathrm{J}_{2}: \sim \mathrm{E}-\mathrm{W}, \mathrm{J}_{1 \mathrm{~V}}\right.$ : $\sim \mathrm{NE}-\mathrm{SW}, \mathrm{J}_{2 \mathrm{~V}}: \sim \mathrm{WNW}-\mathrm{ESE}$ ) are analysed individually for palaeostress directions (figure 11 for $\mathrm{J}_{1}$ and $\mathrm{J}_{2}$; figure 12 for $\mathrm{J}_{1 \mathrm{~V}}$ and $\mathrm{J}_{2 \mathrm{~V}}$ ). Finally, as a separate run, all the 100 joints are analysed (figure 13). 

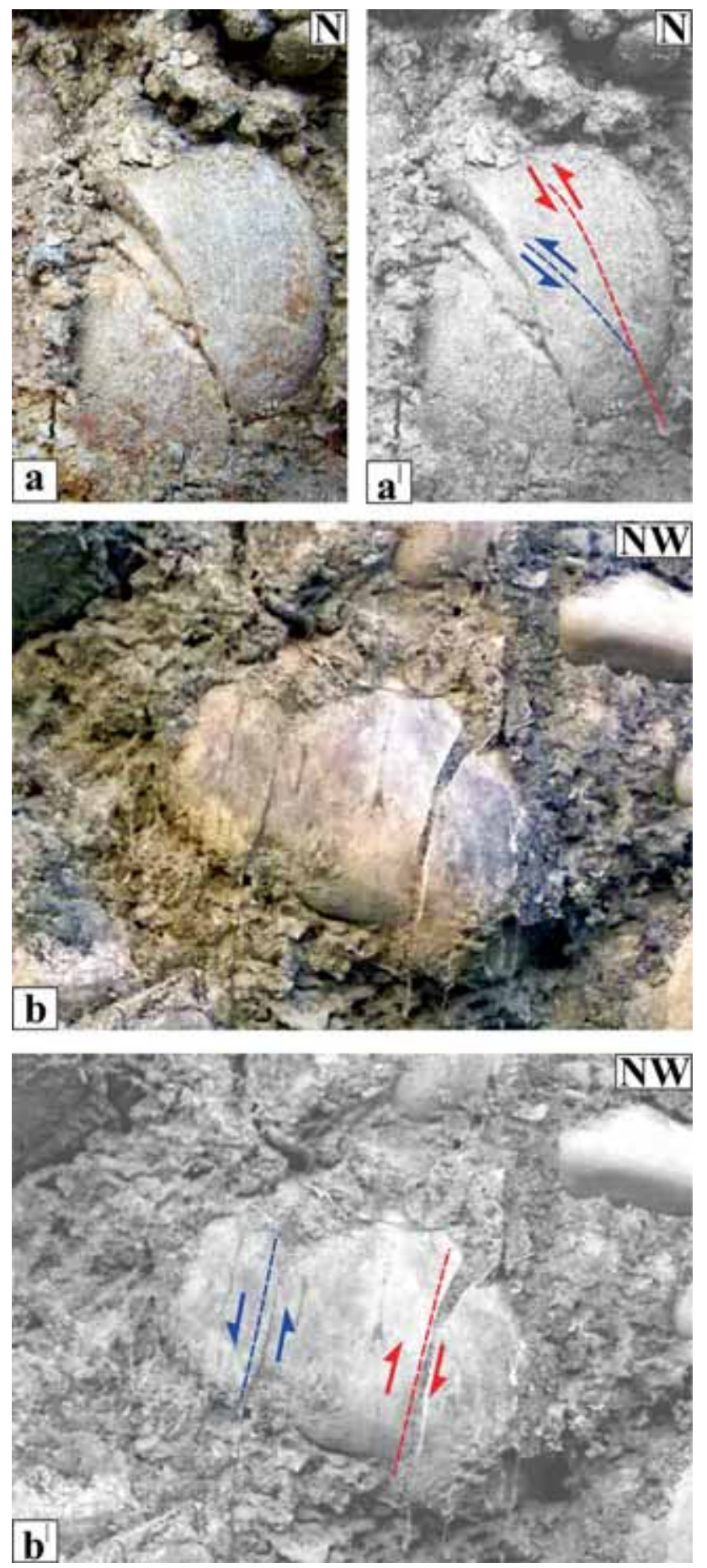

Figure 9. (a and b) Near-vertical faults. Two separate fault planes within a single clast. Width of view for (a) is $\sim 3 \mathrm{~cm}$. Long axis of the pebble in (b) is $\sim 14 \mathrm{~cm}$.

\subsection{Results}

Figures 11-13 present the results of the palaeostress analyses. All of them indicate a strike-slip tectonic regime. The present numerical algorithm of T-TECTO Studio X5 does not determine the stress ratio using only planar data (without fault-slip data) (Jure Žalohar, personal communication) and hence has not been discussed. The $\sigma_{1}$-axis is deciphered to be along $\sim \mathrm{NW}-\mathrm{SE}$, when both the $\mathrm{J}_{1}$ and $\mathrm{J}_{2}$ inclined joints are considered (figure 11a). The outcome resembles when $\mathrm{J}_{2}$ is considered alone (figure $11 \mathrm{~b}$ ). However, when only $\mathrm{J}_{1}$ is considered, the maximum compressive direction is $\sim \mathrm{ENE}-$ WSW (figure $11 \mathrm{c}$ ). $\mathrm{J}_{1 \mathrm{~V}}$ and $\mathrm{J}_{2 \mathrm{~V}}$ analysed together reveal $\sim$ ENE-WSW compression (figure 12a). The compression directions are $\sim$ ENE-WSW and $\sim N W-S E$, individually for $\mathrm{J}_{1 \mathrm{~V}}$ (figure $12 \mathrm{~b}$ ) and $\mathrm{J}_{2 \mathrm{~V}}$ (figure 12c), respectively (table 1). Around ENE-WSW, compression is also the result of the program being run with all the inclined and the near-vertical joints $(n=100)$ (figure 13). When all the inclined joint sets are considered individually, none of the stress axes are deduced to be mutually perpendicular, for $\mathrm{J}_{1}: \angle \sigma_{1}, \sigma_{2}=\angle \sigma_{2}, \sigma_{3}=89^{\circ}$ and $\angle \sigma_{1}, \sigma_{3}=54^{\circ}$; and for $\mathrm{J}_{2}: \angle \sigma_{1}, \sigma_{2}=89^{\circ}$, $\angle \sigma_{2}, \sigma_{3}=88^{\circ}$ and $\angle \sigma_{1}, \sigma_{3}=128^{\circ}$ (figure $11 \mathrm{~b}$ and c; table 1). This, however, does not necessarily indicate a non-Andersonian stress regime. For planar data (only joints or fractures), the VGF method does not use a tensor to calculate the stress/strain axes. Hence, it fails to calculate mathematical solutions that are geologically correct, i.e., mutually perpendicular stress axes (Jure Žalohar, personal communication). But this is not the case when the following joints are taken together: $\mathrm{J}_{1}$ and $\mathrm{J}_{2}$ (figure 11a and table 1 ) and $\mathrm{J}_{1 \mathrm{~V}}$ and $\mathrm{J}_{2 \mathrm{~V}}$ (figure $12 \mathrm{a}-\mathrm{c}$ ).

\section{Discussions}

Along the Dehradun-Roorkee transect, the Upper Siwalik rocks are jointed (e.g., Rautela and Sati 1996; Srivastava and John 1999; Thakur and Pandey 2004, etc.). Srivastava and John (1999) classified joints in the NW trending $\sim 40 \mathrm{~km}$ long Mohand-Khara transect (area SJ in figure 2) into four sets based on their angular relationship with the NW trending axis of the Mohand anticline. Those are (i) $\mathrm{N}^{\circ} 30^{\circ}$ strike-set joints, (ii) $\mathrm{N} 240^{\circ}$ cross-fold joints, (iii) $\mathrm{N} 180^{\circ}$ oblique I joints and (iv) $\mathrm{N}^{\circ} 0^{\circ}$ oblique II joints. $\mathrm{J}_{1}$ and $\mathrm{J}_{2}$ described in this study, are similar to the above-mentioned (i) and (iv) joint classifications, respectively. However, joints $\mathrm{J}_{1 \mathrm{~V}}$ and $\mathrm{J}_{2 \mathrm{~V}}$ are new reports in this area.

Srivastava and John (1999) also report seven types of faults from within the mudstone-sandstone layers of the Middle Siwalik Subgroup. Based on the angle between the fault's strike with 

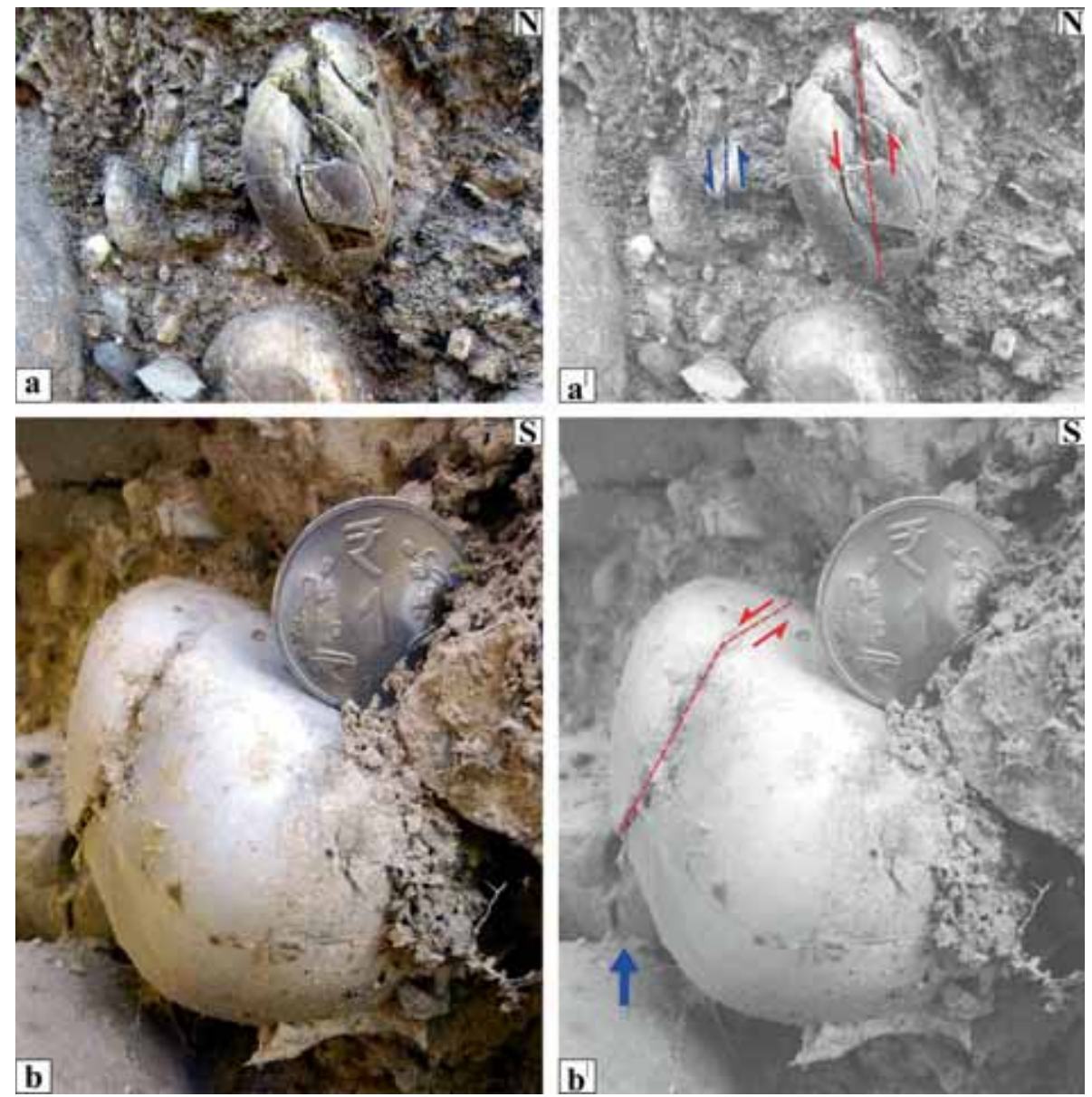

Figure 10. (a) Near-vertical faulted clast. (b) Sinistral component (red half-arrows) deciphered in an apparent vertical movement. The fault also continues through another clast (blue arrow). Diameter of the coin in (b): $2 \mathrm{~cm}$.

that of the axial plane of the Mohand anticline, four of them were classified as: (a) strike ( $\sim \mathrm{NW}-$ SE trending); (b) cross-fold ( $\sim \mathrm{NE}-\mathrm{SW}$ trending); (c) oblique-I ( $\sim$ ENE-WSW trending) and (d) oblique-II ( WSW-ESE trending) faults. According to the authors, these faults exhibit both normal and reverse shear senses. The authors attributed the reverse movement to a late horizontal compression. The rest were termed as (e) low dipping; (f) steeply dipping and (g) conjugate. Steeply dipping faults of both normal (top-to-SW down, top-to-NE down) and reverse (top-to-SW up) types are reported (Srivastava and John 1999), whereas the other two (e and g) exhibit only normal shear sense (top-to-SSE down, top-to-NNE down, top-to-SSW down). Several reasons were proposed by the authors to explain the origin of these faults (e-g) such as soft-sediment deformation, palaeoseismicity-induced liquefaction, etc. The eight fault slip senses $\left(\mathrm{F}_{1}-\mathrm{F}_{8}\right)$ reported in the present study are possibly consequences of both regional and local deformation. $\mathrm{F}_{2}$ (top-to-SW up) and $\mathrm{F}_{3}$ (top-to-NE up) may have originated during the Himalayan compression, but the accurate reasons for the geneses of the rest remain unclear.

The trends of a specific set of near-vertical faults and those of the near-vertical joints are similar (figure 4b). Faulting might occur later on earlier formed joints (Gibson 1969; Roberts 1975; Winslow 1983; Mandl 2005; Faulkner et al. 2008; Bhola et al. 2011; Pastor-Galán et al. 2011; Yang et al. 2017). The presence of near-parallel joints and faults can signify an age gap between them (Hancock 1985), and in such cases, joints tend to develop before faulting (Segall and Pollard 1983). Near-vertical faults from this portion of the Siwalik Himalaya have been reported and linked with isostatic imbalance/adjustment (Raiverman 2012; also see Jones 1980; Sissons and Cornish 1982). Based on gravity and seismic studies, Qureshy et al. (1974) too favoured vertical tectonics from this area. Moreover, vertical faults can also be related to strike-slip 


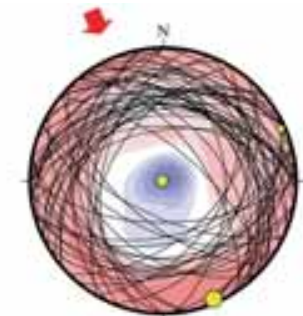

a

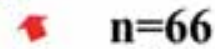

b

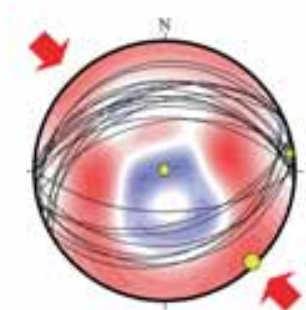

$n=24$

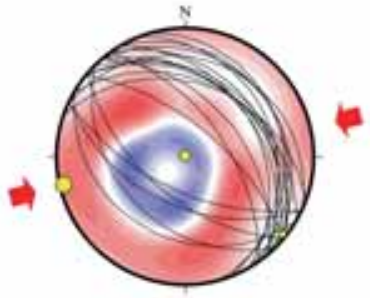

c

$\mathbf{n}=\mathbf{2 2}$
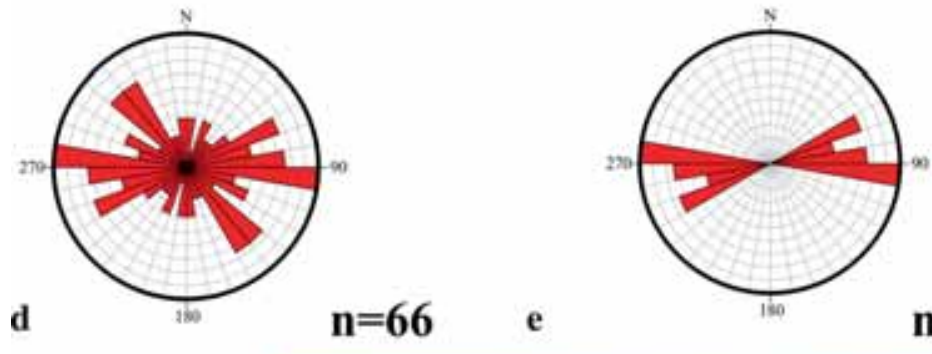

e

$n=24$

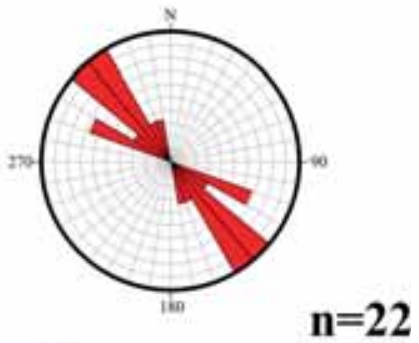

minimum

compression
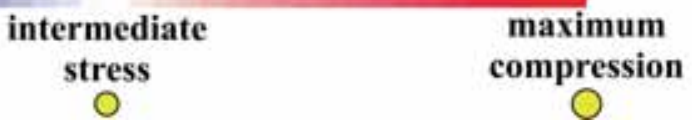

Figure 11. Palaeostress results of inclined joints: (a) all joints, (b) $\mathrm{J}_{1}$ set of joints, (c) $\mathrm{J}_{2}$ set of joints, (d-f) are rose plots of the trend of joints in $(\mathrm{a}-\mathrm{c})$, respectively. $n$ : number of joints analysed. Red arrows: direction of maximum compression.

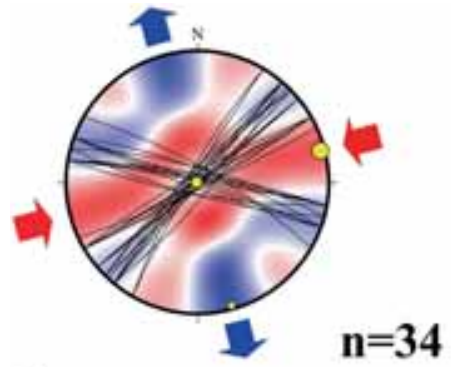

a

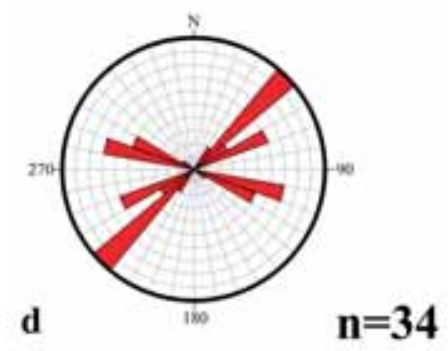

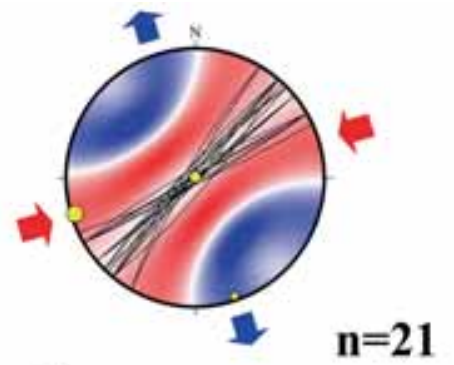

b

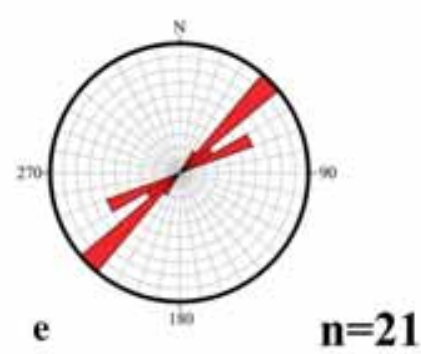

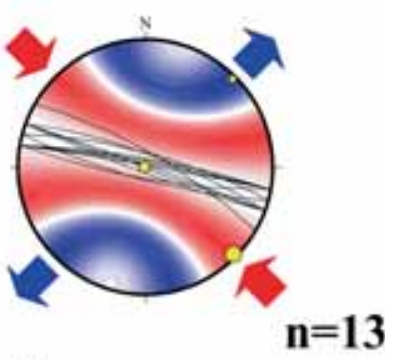

c

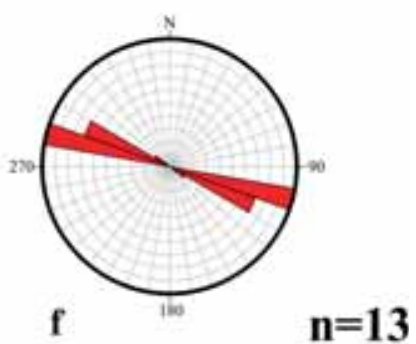

minimum compression

\section{intermediate stress}

maximum compression

Figure 12. Palaeostress results of near-vertical joints: (a) both $\mathrm{J}_{1 \mathrm{~V}}$ and $\mathrm{J}_{2 \mathrm{~V}},(\mathbf{b}) \mathrm{J}_{1 \mathrm{~V}}$ joint set, (c) $\mathrm{J}_{2 \mathrm{~V}}$ joint set, (d-f) are rose plots of the trend of joints in $(\mathrm{a}-\mathrm{c})$, respectively. $n$ : number of joints analysed. Red arrows: direction of maximum compression. 
$\mathbf{a}$

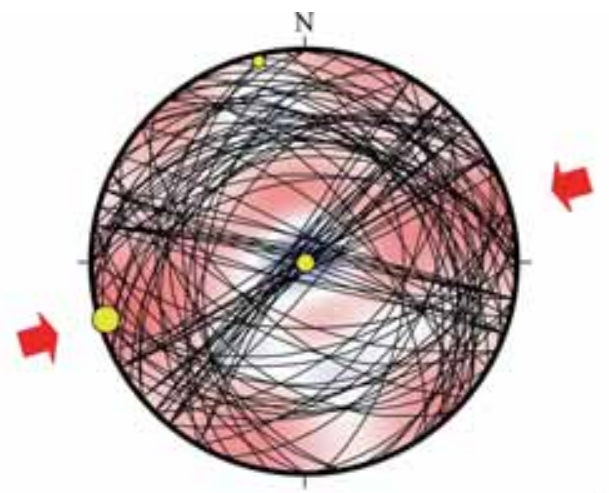

$\mathbf{n}=\mathbf{1 0 0}$

b

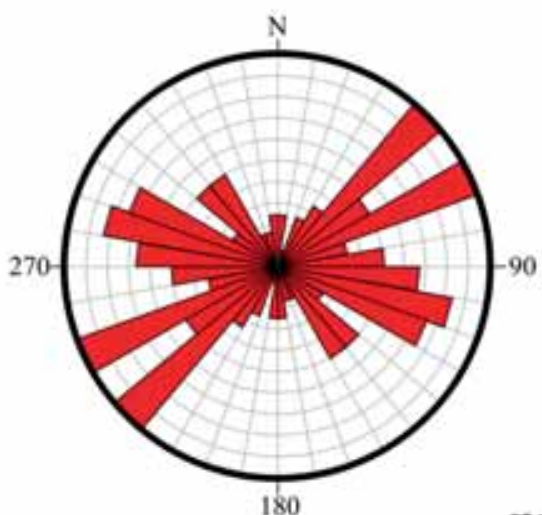

$\mathrm{n}=\mathbf{1 0 0}$

\section{minimum \\ compression}

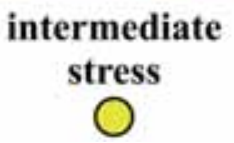

maximum compression

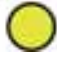

Figure 13. Palaeostress results of both inclined and nearvertical joints. Trend of joints in (a) are plotted in (b). Red arrows: direction of maximum compression.

tectonics, e.g., in the contexts of positive and negative flower structures (figure 19.16 of Fossen 2016). The trends of 6 out of 35 vertical faults reported in the present study nearly match with those of the S1-S3 and the GTF. However, this needs to be studied in detail with more data sets.

Carey (1955) defined an orocline as an initially linear orogen that developed an arcuate morphology during subsequent deformation. Several mechanisms have been proposed so far to explain the origin of curvature of the orogens (Weil and Sussman 2004 and references therein). Arc-parallel compression, at a late-stage of orogeny, has been suggested as one of the factors (Johnston et al. 2013 and references therein). Arc-parallel compression in

the Himalaya is so far reported from the syntaxes (Treloar et al. 1991; Sana and Nath 2016) and to the $\mathrm{S}$ of the Main Mantle Thrust in NW Himalaya (Pakistan) (Sayab et al. 2016). The rate of arc-parallel shortening near the Nanga Parbat syntaxis is $\sim 12 \mathrm{~mm} \mathrm{yr}^{-1}$ (Seeber and Pêcher 1998). Arcuate orogens often exhibit radial convergence that compensates for the arc-parallel extension of the hanging wall material (Southern Tibet in the case of the Himalayan arc) (Ni and Barazangi 1985; McCaffrey 1992). Burg et al. (2005) report a transpressional regime close to the Hazara syntaxis (Pakistan) in the NW Himalaya. Palaeostress reconstructions conducted by these authors using fault-slip data reveal both NW-SE and E-W compression, the former being dominant.

When $\mathrm{J}_{1}$ and $\mathrm{J}_{2}$ joints are analysed together, this study indicates arc-parallel compression (figure 11a). Hence, these joint sets developed presumably during later stages of orogenesis, i.e., after the initial arc-perpendicular compression. The near-vertical joint sets $\left(\mathrm{J}_{1 \mathrm{~V}}\right.$ and $\left.\mathrm{J}_{2 \mathrm{~V}}\right)$ indicate $76^{\circ} \mathrm{N}$ trending $\sigma_{1}$-axis (figure $12 \mathrm{a}$ ). However, $\mathrm{J}_{1 \mathrm{~V}}$ and $\mathrm{J}_{2 \mathrm{~V}}$, when considered individually, reveal $\sim \mathrm{ENE}-\mathrm{WSW}\left(253^{\circ} \mathrm{N}\right)$ (figure $12 \mathrm{~b}$ ) and $\sim \mathrm{NW}-\mathrm{SE}$ $\left(135^{\circ} \mathrm{N}\right)$ (figure $12 \mathrm{c}$ ) compression, respectively. Furthermore, as already stated in section 4.3, palaeostress studies on all joints (inclined and near-vertical) reveal $\sim$ ENE-WSW compression (figure 13). Two possibilities arise: (a) all joints developed during an early stage of orogeny (arcperpendicular compression, figure 13) and (b) both $\mathrm{J}_{1 \mathrm{~V}}$ and $\mathrm{J}_{2 \mathrm{~V}}$ developed by arc-perpendicular compression (figure 12a) and prior to $\mathrm{J}_{1}$ and $\mathrm{J}_{2}$. The latter two joint sets developed possibly by arcparallel compression (figure 11a). Tensional joint sets, developed during oroclinal bending due to arcparallel shortening, have been documented from the sedimentary formations of the CantabrianAsturian arc (Spain). From this place, joints both parallel and perpendicular to the shortening direction $\left(\sigma_{1}\right)$ are reported (Pastor-Galán et al. 2011).

Arc-parallel compression tends to be prevalent in the inner arc of an arcuate orogenic belt (GutiérrezAlonso et al. 2012; Weil Viti et al. 2013). In this study, however, the field locations lie close to the outer arc of the Himalaya. Hence, as it appears, arc-parallel compression is not always restricted to the inner arc of an orogen. If not regional, localised switching of the principal stress axes could be the case here. 2D finite element models of Engelder and Peacock (2001) showed that increased shear traction can induce such localised 
Table 1. Results of the palaeostress analysis.

\begin{tabular}{lcccc}
\hline & & \multicolumn{3}{c}{$\begin{array}{c}\text { Orientations of principal stress } \\
\text { axes (trend/plunge) }\end{array}$} \\
\cline { 3 - 5 } Joints & & $\sigma_{1}$ & $\sigma_{2}$ & $\sigma_{3}$ \\
\hline Inclined (figure 11) & All & $157 / 0$ & $289 / 89$ & $66 / 1$ \\
& $\mathrm{~J}_{1}$ & $136 / 1$ & $327 / 89$ & $82 / 0$ \\
& $\mathrm{~J}_{2}$ & $257 / 0$ & $10 / 89$ & $129 / 1$ \\
Near-vertical (figure 12) & $\mathrm{All}$ & $76 / 1$ & $277 / 89$ & $164 / 0$ \\
& $\mathrm{~J}_{1 \mathrm{~V}}$ & $253 / 0$ & $9 / 89$ & $162 / 1$ \\
& $\mathrm{~J}_{2 \mathrm{~V}}$ & $135 / 0$ & $270 / 90$ & $45 / 0$ \\
Both inclined and near-vertical & & $254 / 0$ & $128 / 89$ & $347 / 0$ \\
$\quad$ figure 13) & & & & \\
\hline
\end{tabular}

stress reorientation in stiffer layers. Consequently, tensile joints (syn-folding) perpendicular to the regional $\sigma_{1}$ direction can develop. The stiffness contrast also plays an important role in stress reorientation, especially across the rheological interfaces, thereby affecting the mechanics of jointing (Tindall and Eckert 2015). Such a sharp rheological contrast is found between the clasts and the matrix of conglomerates. Localised compression (near-perpendicular to the regional compression) may also occur in between close-spaced normal faults at a high angle to the orogenic trend due to regional extension (figure 4 of Seeber and Pêcher 1998). The absence of such normal faults in and around our study area (based on previous literature and our fieldwork), however, does not favour that possibility. On the other hand, analytical studies conducted by Chester and Fletcher (1997) reveal that the local stress directions, in the vicinity of a fault bend, may deviate (by $\sim 90^{\circ}$ ) from the regional stress orientation. Hence, the slight curvature of the thrust planes, viz., the MFT and the Asan Thrust (figure 2) (as observed in plan view) near our study area might also be responsible for the $\sim \mathrm{NW}-\mathrm{SE}$ compression.

Johnston et al. (2013) discuss the possibility of strike-slip faults (parallel or perpendicular to the orogenic trend) for orogens undergoing (or have undergone) arc-parallel compression. Del Greco et al. (2016) report strike-slip faults $\sim$ perpendicular to the Variscan fold and thrust belt due to post-Variscan arc-parallel compression. In the Himalayan context, similar high-angle strike-slip faults are also present close to our study area, viz., E1 ( 15 km NE of Mohand), E2 ( 22 km SE of Mohand), S1 ( $\sim 17 \mathrm{~km}$ SE of Mohand), S2 (passing through Mohand and Dehradun), S3 ( $\sim 30 \mathrm{~km} \mathrm{NW}$ of Mohand), the YTF ( $\mathrm{N}$ of S3) and the GTF ( $25 \mathrm{~km}$ SE of Mohand) (figure 2). $\mathrm{Hu}$ and Angelier (2004), with the help of 3D distinct element modelling, inferred that low values of stress ratios $\left(\Phi<0.5\right.$, where $\Phi=\left[\sigma_{2}-\sigma_{3}\right] /$ $\left.\left[\sigma_{1}-\sigma_{3}\right]\right)$ can induce changes from reverse (vertical $\sigma_{3}$ ) to the strike-slip (vertical $\sigma_{2}$ ) mode of faulting in compressional regimes. The authors further state that such stress permutations are especially common for brittle deformations. $\Phi$ could not be revealed from the palaeostress analyses conducted in this study. Nevertheless, local strikeslip faulting (figures 2 and 11-13) in a tectonic setting where thrust nappes and regional scale crustal stacking are more prevalent (Jain et al. 2000; Yin 2006; Mukherjee 2015), possibly indicates a $\Phi<0.5$. Moreover, rheological variations can also cause stress permutations and anisotropic rocks such as conglomerates are more prone to this phenomenon ( $\mathrm{Hu}$ and Angelier 2004). Field data and palaeostress analyses from Rhenish massif (Germany) show that deformation-induced inhomogeneity or anisotropy in an otherwise isotropic medium can also reorient the stress axes (Oncken 1988). Besides, the local strike-slip faults could also have originated due to the presence of the $\sim \mathrm{NE}-\mathrm{SW}$ trending Delhi-Haridwar ridge (DHR) south of the MFT (Godin et al. 2018 and references therein). The DHR could have acted as a rigid indenter to the foreland propagating thrust sheets, thereby inducing strike-slip deformation in its immediate vicinity. Such a genesis for strike-slip faults, at a high angle to the thrust planes, has been observed in sandbox models (Macedo and Marshak 1999). This indentation of the MFT by the DHR can also explain the bend (convex towards north) of the hinge of Mohand anticline (figure 2; also read Singh and Jain 2009). Compared to the regional stress regime, our results of palaeostress analyses 


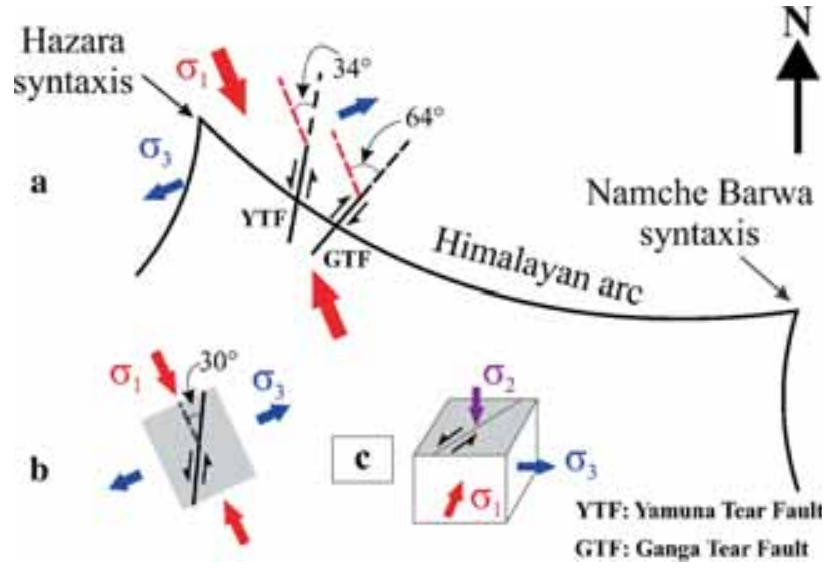

Figure 14. Cartoon depicting the plausible genesis of the YTF due to arc-parallel compression. (a) Location and orientation of the strike slip-faults. Red and black dotted lines parallel the compression direction and faults, respectively. (b) Strike-slip Andersonian stress regime and the map view. (c) 3D block diagram showing orientation of principal stress axes. Half-arrows connote slip sense. Red arrows: maximum principal stress, pink arrow: intermediate principal stress and blue arrow: minimum principal stress.

reveal two major findings, viz., (i) reorientation of $\sigma_{1}(\sim \mathrm{NW}-\mathrm{SE})$ and (ii) switching of $\sigma_{2}$ and $\sigma_{3}$. Similar stress reorientations have also been reported from the Zagros fold-thrust belt (Kermanshah and Shiraz in SW Iran) (Navabpour and Barrier 2012 and references therein). Hence, arc-parallel compression in the NW Himalaya, away from the syntaxial area, seems likely (figure 14). Nevertheless, similar palaeostress investigations along with GPS studies on the southern limb of the Mohand anticline and the sub-Himalayan zone throughout the orogen would certainly aid in confirming the spatial extent of the arc-parallel compression (if any) as well as the potential driving forces.

\section{Conclusions}

Intense brittle deformations, viz., Y- and P-planes, faults and joints are reported from the Upper Siwalik conglomerates NE to Mohand. Eight slip senses are documented in the field: (i) top-to$\mathrm{SW} / \mathrm{SSW}$ down $\left(\mathrm{F}_{1}\right)$; (ii) top-to-SW/SSW up $\left(\mathrm{F}_{2}\right)$; (iii) top-to-NE/NNE up $\left(\mathrm{F}_{3}\right)$; (iv) top-to-NE/ENE down $\left(\mathrm{F}_{4}\right)$; (v) top-to-NW up $\left(\mathrm{F}_{5}\right)$; (vi) top-to$\mathrm{NW} / \mathrm{NNW}$ down $\left(\mathrm{F}_{6}\right)$; (vii) top-to-SE/SSE up $\left(\mathrm{F}_{7}\right)$ and (viii) top-to-SE/SSE down $\left(\mathrm{F}_{8}\right)$. Near-vertical faults $\left(\mathrm{F}_{1 \mathrm{~V}}\right.$ and $\left.\mathrm{F}_{2 \mathrm{~V}}\right)$ and four joint sets (inclined: $\mathrm{J}_{1}$ and $\mathrm{J}_{2}$; near-vertical: $\mathrm{J}_{1 \mathrm{~V}}$ and $\mathrm{J}_{2 \mathrm{~V}}$ ) have also been identified from the field.
We propose that the above-mentioned shear senses (i-viii) are combined products of a regional compressive event and a local event. $\mathrm{F}_{2}$ and $\mathrm{F}_{3}$ possibly developed during arc-perpendicular compression. However, the origin of the remainder $\left(\mathrm{F}_{1}\right.$, $\mathrm{F}_{4}$ and $\mathrm{F}_{5}-\mathrm{F}_{8}$ ) remains indeterminate. They might be products of local deformation. Furthermore, no temporal relation between the faults could be established due to a lack of cross-cutting relations between them in the field. The near-vertical faults may have developed along pre-existing joints. However, the cause of such reactivation remains unclear and requires further research.

Palaeostress studies of the joint sets reveal two dominant compression directions $\sim$ ENE-WSW and $\sim N N W-S S E$. Based on the results, we infer two possibilities: (a) $\mathrm{J}_{1}, \mathrm{~J}_{2}, \mathrm{~J}_{1 \mathrm{~V}}$ and $\mathrm{J}_{2 \mathrm{~V}}$ are coeval and developed by an arc-perpendicular compression or (b) $\mathrm{J}_{1 \mathrm{~V}}$ and $\mathrm{J}_{2 \mathrm{~V}}$ jointing (due to arc-perpendicular compression or arc-parallel extension) was followed by $\mathrm{J}_{1}$ and $\mathrm{J}_{2}$ jointing during late stage arc-parallel compression. Similar to the Andean and Variscan orogens, the presence of strike-slip faults, viz., E1, E2, S1-S3, YTF and GTF, at a high angle to the Himalayan orogenic trend, probably indicate arc-parallel compression at a later stage of the Himalayan orogeny. However, the exact reason for such a compression direction deciphered in this study needs further analogue and analytical studies.

\section{Acknowledgements}

We thank IIT Bombay for funding the 2014 Siwalik fieldwork. DD and TB thank Jure Žalohar for providing the T-TECTO licence and clarifying several software-related queries. DD appreciates the helpful comments from Georg Mandl on the geneses of shear joints. SM thanks IIT Bombay for providing a research sabbatical in 2017. Prof S Gupta's handling and the detailed thoughtful comments by two anonymous reviewers and Prof S Banerjee are gratefully acknowledged.

\section{References}

Angelier J 1984 Tectonic analysis of fault slip data sets; J. Geophys. Res. Solid Earth 89 5835-5848.

Angelier J 1989 From orientation to magnitudes in paleostress determinations using fault slip data; J. Struct. Geol. $1137-50$.

Angelier J 1990 Inversion of field data in fault tectonics to obtain the regional stress - III. A new rapid direct 
inversion method by analytical means; Geophys. J. Int. $103363-376$.

Angelier J and Mechler P 1977 A graphic method applied to the localization of principal stresses for fault tectonics and seismology: The right dihedral method; Bull. Soc. Geol. Fr. 19 1309-1318.

Armijo R, Carey E and Cisternas A 1982 The inverse problem in microtectonics and the separation of tectonic phases; Tectonophys. 82 145-160.

Banerjee S, Matin A and Mukul M 2015 Overburden-induced flattening structure in the Himalaya: Mechanism and implication; Curr. Sci. 109 1-8.

Baudon C and Cartwright J 2008 Early stage evolution of growth faults: 3D seismic insights from the Levant basin, eastern Mediterranean; J. Struct. Geol. 30 888-898.

Bhola A M, Dinkar G K and Singh V K 2011 Analysis of joints in Precambrian rocks of Delhi-Aravalli Belt, Manesar area, Gurgaon district, Haryana, India; In: Proceeding of the 2nd International Conference Precambrian Continental Growth and Tectonism, pp. 978-981.

Billings Marland P 2008 Structural Geology; 3rd edn, Prentice-Hall, New Jersey, 624p, ISBN: 978-8120300590.

Biswas T and Dutta D 2016 Broken pebble with small-scale brittle reverse-fault with top-to-SSE. Photograph of the month; J. Struct. Geol. 85 iii.

Bonini M, Sani F, Moratti G and Benvenuti M G 2011 Quaternary evolution of the Lucania Apennine thrust front area (Southern Italy), and its relations with the kinematics of the Adria Plate boundaries; J. Geodyn. 51 125-140.

Borah K, Kanna N, Rai S S and Prakasam K S 2015 Sediment thickness beneath the Indo-Gangetic plain and Siwalik Himalaya inferred from receiver function modelling; J. Asian Earth Sci. 99 41-56.

Bott M H P 1959 The mechanics of oblique slip faulting; Geol. Mag. 96 109-117.

Boutelier D A and Oncken O 2010 Role of the plate margin curvature in the plateau buildup: Consequences for the central Andes; J. Geophys. Res. Solid Earth 115, https:// doi.org/10.1029/2009JB006296.

Burg J P, Célérier B, Chaudhry N M, Ghazanfar M, Gnehm F and Schnellmann M 2005 Fault analysis and paleostress evolution in large strain regions: Methodological and geological discussion of the southeastern Himalayan fold-and-thrust belt in Pakistan; J. Asian Earth Sci. 24 445-467.

Carey S W 1955 The orocline concept in geotectonics - part I; Pap. Proc. R. Soc. Tasmania 89 255-288.

Carosi R, Montomoli C and Pertusati P C 2002 Late orogenic structures and orogen-parallel compression in the Northern Apennines; Bull. Soc. Geol. Ital. 1 167-180.

Chatterjee S, Goswami A and Scotese C R 2013 The longest voyage: Tectonic, magmatic, and paleoclimatic evolution of the Indian plate during its northward flight from Gondwana to Asia; Gondwana Res. 23 238-267.

Chester J S and Fletcher R C 1997 Stress distribution and failure in anisotropic rock near a bend on a weak fault; J. Geophys. Res. Solid Earth 102 693-708.

Coleman M E 1996 Orogen-parallel and orogenperpendicular extension in the central Nepalese Himalayas; Geol. Soc. Am. Bull. 108 1594-1607.

Copley A, Avouac J P and Royer J Y 2010 India-Asia collision and the Cenozoic slowdown of the Indian plate: Implications for the forces driving plate motions; J. Geophys. Res. Solid Earth 115 B03410.

Conybeare C E B 1979 Lithostratigraphic analysis of sedimentary basins; Academic Press, New York, pp. 1-555.

Craig J, Hakhoo N, Bhat G M, Hafiz M, Khan M R, Misra R, Pandita S K, Raina B K, Thurow J, Thusu B, Ahmed W and Khullar S 2018 Petroleum systems and hydrocarbon potential of the North-West Himalaya of India and Pakistan; Earth Sci. Rev. 187 109-185.

DeCelles P G, Gehrels G E, Najman Y, Martin A J, Carter A and Garzanti E 2004 Detrital geochronology and geochemistry of cretaceous-early miocene strata of Nepal: Implications for timing and diachroneity of initial Himalayan orogenesis; Earth Planet. Sci. Lett. 227313 330.

Del Greco K, Johnston S T, Gutiérrez-Alonso G, Shaw J and Lozano J F 2016 Interference folding and orocline implications: A structural study of the Ponga unit, Cantabrian orocline, northern Spain; Lithosphere 8 757-768.

Delvaux D and Sperner B 2003 Stress tensor inversion from fault kinematic indicators and focal mechanism data: The TENSOR program. New insights into structural interpretation and modelling; Geol. Soc. Spec. Publ. 212 75-100.

Dubey A K 2014 Understanding an orogenic belt. Structural evolution of the Himalaya; Springer, Berlin, 401p, ISBN: 978-3-319-05588-6.

Durand V, Bouchon M, Floyd M A, Theodulidis N, Marsan D, Karabulut H and Schmittbuhl J 2014 Observation of the spread of slow deformation in Greece following the breakup of the slab; Geophys. Res. Lett. 41 7129-7134.

Engelder T and Peacock D C 2001 Joint development normal to regional compression during flexural-flow folding: The Lilstock buttress anticline, Somerset, England; J. Struct. Geol. 23 259-277.

Eidelman A and Reches Z 1992 Fractured pebbles - A new stress indicator; Geology 20 307-310.

Farrell S G 1984 A dislocation model applied to slump structures, Ainsa basin, South Central Pyrenees; J. Struct. Geol. 6 727-736.

Faulkner D R, Mitchell T M, Rutter E H and Cembrano J 2008 On the structure and mechanical properties of large strike-slip faults; In: The internal structure of fault zones: Implications for mechanical and fluid-flow properties (eds) Wibberley C A J, Kurz W, Imber J, Holdsworth R E and Collettini C, Geol. Soc. Spec. Publ. 299 139-150.

Fossen H 2016 Structural Geology; 2nd edn, Cambridge University Press, Cambridge, pp. 1-510. ISBN: 9781107057647.

Garzanti E, Baud A and Mascle G 1987 Sedimentary record of the northward flight of India and its collision with Eurasia (Ladakh Himalaya, India); Geodin. Acta 1 297-312.

Gibson I L 1969 The structure and volcanic geology of an axial portion of the main Ethiopian rift; Tectonophys. 8 561-565.

Godin L, La Roche R S, Waffle L and Harris L B 2018 Influence of inherited Indian basement faults on the evolution of the Himalayan orogen; In: Crustal architecture and evolution of the Himalaya-Karakoram-Tibet orogen (eds) Sharma R, Villa I M and Kumar S, Geol. Soc. London, Spec. Publ. 481, https://doi.org/10.1144/SP481.4.

Goswami P K and Deopa T 2018 Petrotectonic setting of the provenance of lower Siwalik sandstones of the Himalayan 
foreland basin, south eastern Kumaun Himalaya, India; Island Arc 27, https://doi.org/10.1111/iar.12242.

Guillot S, Garzanti E, Baratoux D, Marquer D, Mahéo G and de Sigoyer J 2003 Reconstructing the total shortening history of the NW Himalaya. Geochem. Geophys. Geosyst. 4, https://doi.org/10.1029/2002GC000484.

Gutiérrez-Alonso G, Johnston S T, Weil A B, Pastor-Galán D and Fernández-Suárez J 2012 Buckling an orogen: The Cantabrian orocline; GSA Today 22 4-9.

Hancock P L 1985 Brittle microtectonics: Principles and practice; J. Struct. Geol. 7(3) 437-457.

Hancock P L, Al Kadhi A, Barka A A and Bevan T G 1987 Aspects of analysing brittle structures; Ann. Tecton. 1 $5-19$.

Hintersberger E, Thiede R C, Strecker M R and Hacker B R 2010 East-west extension in the NW Indian Himalaya; Geol. Soc. Am. Bull. 122 1499-1515.

Hippolyte J C 2001 Palaeostress and neotectonic analysis of sheared conglomerates: Southwest Alps and Southern Apennines; J. Struct. Geol. 23 421-429.

Hu J C and Angelier J 2004 Stress permutations: Threedimensional distinct element analysis accounts for a common phenomenon in brittle tectonics; J. Geophys. Res. Solid Earth 109, https://doi.org/10.1029/2003JB002616.

$\mathrm{Hu}$ X, Wang J, BouDagher-Fadel M, Garzanti E and An W 2016 New insights into the timing of the India-Asia collision from the Paleogene Quxia and Jialazi formations of the Xigazeforearc basin, South Tibet; Gond. Res. 32 $76-92$.

Jagoutz O, Royden L, Holt A F and Becker T W 2015 Anomalously fast convergence of India and eurasia caused by double subduction; Nat. Geosci. 8 475-478.

Jain A K, Kumar D, Singh S, Kumar A and Lal N 2000 Timing, quantification and tectonic modelling of PlioceneQuaternary movements in the NW Himalaya: Evidence from fission track dating; Earth Planet. Sci. Lett. 179 437-451.

Jayangondaperumal R, Dubey A K and Sen K 2010 Structural and magnetic fabric studies of recess structures in the western Himalaya: Implications for 1905 Kangra earthquake; J. Geol. Soc. In. 75 225-238.

Jayangondaperumal R, Thakur V C, Joevivek V, Rao P S and Gupta A K 2018 Active tectonics of Kumaun and Garhwal Himalaya; Springer, Singapore, pp. 61-78, ISBN: 978-981-10-8243-6.

Jessup M J and Cottle J M 2010 Progression from southdirected extrusion to orogen-parallel extension in the southern margin of the Tibetan plateau, Mount Everest region, Tibet; J. Geol. 118 467-486.

Jessup M J, Newell D L, Cottle J M, Berger A L and Spotila J A 2008 Orogen-parallel extension and exhumation enhanced by denudation in the trans-Himalayan Arun River gorge, Ama Drime Massif, Tibet-Nepal; Geology 36 587-590.

Johnston S T, Weil A B and Gutiérrez-Alonso G 2013 Oroclines: Thick and thin; Geol. Soc. Am. Bull. 125 643-663.

Jones R M P 1980 Basinalisostatic adjustment faults and their petroleum significance; Bull. Can. Petrol. Geol. $\mathbf{2 8}$ 211-251.

Karunakaran C and Rao R 1976 Status of hydrocarbon in the Himalayan region: Contributions to stratigraphy and structure; Geol. Surv. India Misc. Publ. 41 1-66.
Kaven J O, Maerten F and Pollard D D 2011 Mechanical analysis of fault slip data: Implications for paleostress analysis; J. Struct. Geol. 33 78-91.

Khan P K, Ansari M A and Mohanty S 2014 Earthquake source characteristics along the arcuate Himalayan belt: Geodynamic implications; J. Earth Syst. Sci. 123 10131030 .

Konstantinou K I, Kalogeras I S, Melis N S, Kourouzidis M C and Stavrakakis G N 2006 The 8 January 2006 earthquake (Mw 6.7) offshore Kythira Island, Southern Greece: Seismological, strong-motion, and macroseismic observations of an intermediate-depth event; Seismol. Res. Lett. $77544-553$.

Kumar R, Ghosh S K, Mazari R K and Sangode S J 2003 Tectonic impact on the fluvial deposits of plio-pleistocene Himalayan foreland basin, India; Sedim. Geol. 158 209234.

Langille J M, Jessup M J, Cottle J M, Newell D and Seward G 2010 Kinematic evolution of the Ama Drime detachment: Insights into orogen-parallel extension and exhumation of the Ama Drime Massif, Tibet-Nepal; J. Struct. Geol. 32 900-919.

Lavé J and Avouac J P 2000 Active folding of fluvial terraces across the Siwalik Hills, Himalayas of central Nepal; J. Geophys. Res. 105 5735-5770.

Lisle R J 1988 Romsa: A basic program for paleostress analysis using fault-striation data; Comput. Geosci. 14 255-259.

Llana-Fúnez S, Burg J P, Hussain S S, Dawood H and Chaudhry M N 2006 Structural evolution of the footwall of the Indus suture in Malakand (N Pakistan) during the Himalayan collision; J. Asian Earth Sci. 27 691-706.

MacDonald J, Backé G, King R, Holford S and Hillis R 2012 Geomechanical modelling of fault reactivation in the ceduna Sub-basin, bight basin, Australia; In: Faulting, fracturing and igneous intrusion in the earth's crust (eds) Healy D, Butler R W H, Shipton Z K and Sibson R H, Geol. Soc. London, Spec. Publ. 367 71-89.

Macedo J and Marshak S 1999 Controls on the geometry of fold-thrust belt salient; Geol. Soc. Am. Bull. 1111808 1822 .

Mandal S, Robinson D M, Khanal S and Das O 2015 Redefining the tectonostratigraphic and structural architecture of the almora klippe and the Ramgarh-Munsiari thrust sheet in NW India; In: Tectonics of the Himalaya (eds) Mukherjee S, Carosi R, van der Beek P, Mukherjee B K and Robinson D, Geol. Soc. London, Spec. Publ. 412 247269.

Mandl G 2005 Rock joints. The mechanical genesis (1st edn); Springer, Berlin, 221p, ISBN: 978-3-540-26457-6.

Marrett R and Allmendinger R W 1990 Kinematic analysis of fault-slip data; J. Struct. Geol. 12 973-986.

Mazzini A, Jonk R, Duranti D, Parnell J, Cronin B and Hurst A 2003 Fluid escape from reservoirs: Implications from cold seeps, fractures and injected sands part I. The fluid flow system; J. Geochem. Exp. 78 293-296.

McCaffrey R 1992 Oblique plate convergence, slip vectors, and forearc deformation; J. Geophys. Res. 97 8905-8915.

Misra A A, Bhattacharya G, Mukherjee S and Bose N 2014 Near N-S paleo-extension in the western Deccan region, India: Does it link strike-slip tectonics with IndiaSeychelles rifting? Int. J. Earth Sci. 103 1645-1680. 
Mukherjee S 2007 Geodynamics, deformation and mathematical analysis of metamorphic belts of the NW Himalaya; Unpublished PhD Thesis, Indian Institute of Technology Roorkee, pp. 1-267.

Mukherjee S 2010a Structures at meso and micro-scales in the Sutlej section of the higher Himalayan shear zone in Himalaya; e-Terra 7 1-27.

Mukherjee S 2010b Microstructures of the zanskar shear zone; Earth Sci. Ind. 3 9-27.

Mukherjee S 2012 Simple shear is not so simple! kinematics and shear senses in newtonian viscous simple shear zones; Geol. Mag. 149 819-826.

Mukherjee S 2013a Atlas of shear zone structures in mesoscale; Springer, Berlin, 111p, ISBN: 978-3-319-00089-3.

Mukherjee S 2013b Higher Himalaya in the Bhagirathi section (NW Himalaya, India): Its structures, backthrusts and extrusion mechanism by both channel flow and critical taper mechanisms; Int. J. Earth Sci. 102 1851-1870.

Mukherjee S 2013c Deformation microstructures in rocks; Springer, Berlin, 111p, ISBN: 978-3-642-25608-0.

Mukherjee S 2014 Review of flanking structures in meso- and micro-scales; Geol. Mag. 151 957-974.

Mukherjee S 2015 A review on out-of-sequence deformation in the Himalaya; In: Tectonics of the Himalaya (eds) Mukherjee S, Carosi R, van der Beek P, Mukherjee B K and Robinson D, Geol. Soc. London, Spec. Publ. 412 67109.

Mukherjee S and Koyi H A 2010a Higher Himalayan shear zone, Sutlej section: Structural geology and extrusion mechanism by various combinations of simple shear, pure shear and channel flow in shifting modes; Int. J. Earth Sci. 99 1267-1303.

Mukherjee S and Koyi H A 2010b Higher Himalayan shear zone, zanskar Indian Himalaya microstructural studies and extrusion mechanism by a combination of simple shear and channel flow; Int. J. Earth Sci. 99 1083-1110.

Mukherjee S and Khonsari M M 2017 Brittle rotational faults and the associated shear heating; Mar. Petrol. Geol. 88 $551-554$.

Murphy M A and Copeland P 2005 Transtensional deformation in the central Himalaya and its role in accommodating growth of the Himalayan orogeny; Tectonics 24 TC4012.

Najman Y, Jenks D, Godin L, Boudagher-Fadel M, Millar I, Garzanti E, Horstwood M and Bracciali L 2017 The Tethyan Himalayan detrital record shows that India-Asia terminal collision occurred by $54 \mathrm{Ma}$ in the Western Himalaya; Earth Planet. Sci. Lett. 459 301-310.

Nanda A C 2002 Upper Siwalik mammalian faunas of India and associated events; J. Asian Earth Sci. 21 47-58.

Nagy C, Godin L, Antolín B, Cottle J and Archibald D 2015 Mid-Miocene initiation of orogen-parallel extension, NW Nepal Himalaya; Lithosphere 7 483-502.

Navabpour P and Barrier E 2012 Stress states in the Zagros fold-and-thrust belt from passive margin to collisional tectonic setting; Tectonophys. 581 76-83.

Nemcok M, Kovác D and Lisle R J 1999 A stress inversion procedure for polyphasercalcite twin and fault/slip data sets; J. Struct. Geol. 21 597-611.

Nemcok M and Lisle R J 1995 A stress inversion procedure for polyphase fault/slip datasets; J. Struct. Geol. 17 1445-1453.
Ni J and Barazangi M 1985 Active tectonics of the western Tethyan Himalaya above the underthrusting Indian plate: The upper Sutlej river basin as a pull-apart structure; Tectonophys. 112 277-295.

Oncken O 1988 Aspects of the reconstruction of the stress history of a fold and thrust belt (Rhenish Massif, Federal Republic of Germany); Tectonophys. 152 19-40.

Parameswaran R M and Rajendran K 2016 The $2016 M_{\mathrm{w}} 6.7$ Imphal earthquake in the Indo-Burman range: A case of continuing intraplate deformation within the subducted slab; Bull. Seismol. Soc. Am. 106 2653-2662.

Passchier C W and Trouw R A 2005 Microtectonics; 2nd edn, Springer, Berlin, 366p. ISBN: 978-3-540-29359-0.

Pastor-Galán D, Gutiérrez-Alonso G and Weil A B 2011 Orocline timing through joint analysis: Insights from the Ibero-Armorican Arc; Tectonophys. 507 31-46.

Peresson H and Decker K 1997 The tertiary dynamics of the northern eastern Alps (Austria): Changing palaeostresses in a collisional plate boundary; Tectonophys. 272 125-157.

Petersen K, Clausen O R and Korstgård J A 1992 Evolution of a salt-related listric growth fault near the D-1 well, block 5605, Danish North Sea: Displacement history and salt kinematics; J. Struct. Geol. 14 565-577.

Powers P M, Lillie R J and Yeats R S 1998 Structure and shortening of the Kangra and Dehradun re-entrants, Sub Himalaya; Geol. Soc. Am. Bull. 110 1010-1027.

Prasad B R, Klemperer S L, Rao V V, Tewari H C and Khare P 2011 Crustal structure beneath the Sub-Himalayan fold-thrust belt, Kangra recess, northwest India, from seismic reflection profiling: Implications for Late Paleoproterozoic orogenesis and modern earthquake hazard; Earth Planet. Sci. Lett. 308 218-228.

Qureshy M N, Venkatachalam S and Subrahmanyam C 1974 Vertical tectonics in the Middle Himalayas: An appraisal from recent gravity data; Geol. Soc. Am. 85 921-926.

Raiverman V 2012 Unconformity-riddled cenozoics of the foreland basin and elevation of the Himalaya; Ind. Geol. Cong., Roorkee, 147p, ISBN: 9788192072401.

Rautela P and Sati D 1996 Recent crustal adjustment on Dehradun valley, western Uttar Pradesh, India; Curr. Sci. $71776-780$.

Roberts J C 1975 Jointing and minor tectonics of the S. Crop of the South Wales coalfield between Machen and Bridgend; Geol. J. 10 147-160.

Rowley D B 1996 Age of initiation of collision between India and Asia: A review of stratigraphic data; Earth Planet. Sci. Lett. 145 1-13.

Sana H and Nath S K 2016 In and around the HazaraKashmir syntaxis: A Seismotectonic and seismic hazard perspective; J. Ind. Geophys. Union 20 496-505.

Sandhu M, Kumar D and Teotia S S 2017 Estimation of site amplification functions for the National Capital (Delhi) Region, India; Nat. Hazards 85 171-195.

Sayab M, Shah S Z and Aerden D 2016 Metamorphic record of the NW Himalayan orogeny between the Indian plateKohistan Ladakh Arc and Asia: Revelations from foliation intersection axis (FIA) controlled $\mathrm{P}-\mathrm{T}-\mathrm{t}-\mathrm{d}$ paths; Tectonophys. 671 110-126.

Saylor J, DeCelles P, Gehrels G, Murphy M, Zhang R and Kapp P 2010 Basin formation in the high Himalaya by arc-parallel extension and tectonic damming: Zhada basin, southwestern Tibet; Tectonics 29 1-24. 
Seeber L and Pêcher A 1998 Strain partitioning along the Himalayan arc and the Nanga Parbat antiform; Geology 26 791-794.

Segall P and Pollard D D 1983 Nucleation and growth of strike slip faults in granite; J. Geophys. Res. 88 555-568.

Shah S Z, Sayab M, Aerden D and Khan M A 2011 Foliation intersection axes preserved in garnet porphyroblasts from the Swat area, NW Himalaya: A record of successive crustal shortening directions between the Indian plate and Kohistan-Ladakh island Arc; Tectonophys. 509 14-32.

Shan Y and Liang X 2015 Inversion of fault data with low diversity for stress: Principles and applications; J. Struct. Geol. 77 228-238.

Simón J L In Press Forty years of paleostress analysis: Has it attained maturity? J. Struct. Geol., https://doi.org/10. 1016/j.jsg.2018.02.011.

Singh T and Jain V 2009 Tectonic constraints on watershed development on frontal ridges: Mohand ridge, NW Himalaya, India; Geomorphology 106 231-241.

Sissons J B and Cornish R 1982 Differential glacio-isostasic uplift of crustal blocks at Glen Roy, Scotland; Quat. Res. $18268-288$.

Srivastava D C and John G 1999 Deformation in the Himalayan frontal fault zone: Evidence from smallscale structures in Mohand-Khara area, NW Himalaya; In: Geodynamics of the NW Himalaya (eds) Jain A K, Manickavasagam R M, Gond. Res. Mem., Vol. 6, Osaka, Santosh M and Yoshida M (series eds), pp. 273284.

Srivastava V, Mukul M and Barnes J B 2016 Main frontal thrust deformation and topographic growth of the mohand range, northwest Himalaya; J. Struct. Geol. 93 131-148.

Srivastava V, Mukul M, Barnes J B and Mukul M 2018 Geometry and kinematics of Main Frontal thrust-related fault propagation folding in the Mohand Range, northwest Himalaya; J. Struct. Geol. 115, 1-18.

Styron R H, Taylor M H and Murphy M A 2011 Oblique convergence, arc-parallel extension, and the role of strikeslip faulting in the high Himalaya; Geosphere 7 582-596.

Suppe J 1983 Geometry and kinematics of fault-bend folding; Am. J. Sci. 283 689-692.

Thakur V C 2013 Active tectonics of Himalayan frontal fault system; Int. J. Earth Sci. 102 1791-1810.

Thakur V C and Pandey A K 2004 Late quaternary tectonic evolution of Dun in fault bend/propagated fold system, Garhwal Sub-Himalaya; Curr. Sci. 87 1567-1576.

Thakur V C, Pandey A K and Suresh N 2007 Late Quaternary-Holocene evolution of Dun structure and the Himalayan frontal fault zone of the Garhwal SubHimalaya, NW India; J. Asian Earth Sci. 29 305-319.

Tindall S and Eckert A 2015 Geometric and mechanicalstiffness controls on jointing in cataclastic deformation bands; J. Struct. Geol. 77 126-137.

Tranos M D 2012 Slip preference on pre-existing faults: A guide tool for the separation of heterogeneous faultslip data in extensional stress regimes; Tectonophys. $\mathbf{5 4 4}$ $60-74$.

Tranos M D 2015 TR method (TRM): A separation and stress inversion method for heterogeneous fault-slip data driven by Andersonian extensional and compressional stress regimes; J. Struct. Geol. 79 57-74.
Tranos M D 2018 The use of stress tensor discriminator faults in separating heterogeneous fault-slip data with best-fit stress inversion methods. II. Compressional stress regimes; J. Struct. Geol. 102 168-178.

Treloar P J, Potts G J, Wheeler J and Rex D C 1991 Structural evolution and asymmetric uplift of the Nanga Parbat syntaxis, Pakistan Himalaya; Geol. Rund. 80 411-428.

Twiss R J and Unruh J R 1998 Analysis of fault slip inversions: Do they constrain stressor strain rate? J. Geophys. Res. Solid Earth 103 12,205-12,222.

Upton P, Begbie M and Craw D 2008 Numerical modelling of mechanical controls on coeval steep and shallow dipping auriferous quartz vein formation in a thrust zone, Macraes mine, New Zealand; Miner. Depos. 43 23-35.

Valdiya K S 2016 The making of India. Geodynamic evolution; 1st edn, Springer, Berlin, 924p. ISBN: 978-3-31925029-8.

van der Pluijm B A and Marshak S 2004 Earth Structure: An Introduction to Structural Geology and Tectonics; 2nd edn, W. W. Norton \& Company, New York, 145p, ISBN: 978-0393924671.

van Hinsbergen D J, Steinberger B, Doubrovine P V and Gassmöller R 2011 Acceleration and deceleration of IndiaAsia convergence since the cretaceous: Roles of mantle plumes and continental collision; J. Geophys. Res. Solid Earth 116 B008051.

Viti M, De Luca J, Babbucci D, Mantovani E, Albarello D and D'Onza F 2004 Driving mechanism of tectonic activity in the northern Apennines: Quantitative insights from numerical modelling; Tectonics 23, https://doi.org/ 10.1029/2004TC001623.

Wallace R E 1951 Geometry of shearing stress and relation to faulting; J. Geol. 59 118-130.

Wang K and He J 1999 Mechanics of low-stress forearcs: Nankai and Cascadia; J. Geophys. Res. Solid Earth 104 15191-15205.

Weil A B, Gutiérrez-Alonso G, Johnston S T and PastorGalán D 2013 Kinematic constraints on buckling a lithospheric-scale orocline along the northern margin of Gondwana: A geologic synthesis; Tectonophys. 582 2549 .

Weil A B and Sussman A J 2004 Classifying curved orogens based on timing relationships between structural development and vertical-axis rotations; In: Orogenic curvature: Integrating paleomagnetic and structural analyses (eds) Sussman A J and Weil A B, Geol. Soc. Am. Spec. Publ. $3831-15$.

Wesnousky S G, Kumar S, Mahindra R and Thakur V C 1999 Uplift and convergence along the Himalayan frontal thrust of India; Tectonics 18 967-976.

White L T and Lister G S 2012 The collision of India with Asia; J. Geodsy. 56 7-17.

Winslow M A 1983 Clastic dike swarms and the structural evolution of the foreland fold and thrust belt of the southern Andes; Geol. Soc. Am. Bull. 94 1073-1080.

Xu Z, Wang Q, Pêcher A, Liang F, Qi X, Cai Z, Li H and Cao H 2013 Orogen-parallel ductile extension and extrusion of the greater Himalaya in the late oligocene and miocene; Tectonics 32 191-215.

Yamaji A 2000 The multiple inverse method: A new technique to separate stresses from heterogeneous fault-slip data; J. Struct. Geol. 22 441-452. 
Yamaji A, Otsubo M and Sato K 2006 Paleostress analysis using the Hough transform for separating stresses from heterogeneous fault-slip data; J. Struct. Geol. 28 980-990.

Yang X X, Jing H W, Tang C A and Yang S Q 2017 Effect of parallel joint interaction on mechanical behavior of jointed rock mass models; Int. J. Rock Mech. Min. Sci. 92 40-53.

Yin A 2006 Cenozoic tectonic evolution of the Himalayan orogen as constrained by along-strike variation of structural geometry, exhumation history, and foreland sedimentation; Earth-Sci. Rev. 76 1-131.

Žalohar J 2018 The Omega-theory: A New physics of earthquakes; In: Developments in structural geology and tectonics, Vol. 2 (series ed.) Mukherjee S; Elsevier, Amsterdam, 558p, ISBN: 978-0-12-814580-7.

Žalohar J and Vrabec M 2007 Paleostress analysis of heterogeneous fault-slip data: The Gauss method; J. Struct. Geol. 29 1798-1810.
Žalohar J and Vrabec M 2008 Combined kinematic and paleostress analysis of fault-slip data: The multiple-slip method; J. Struct. Geol. 30 16031613.

Žalohar J and Vrabec V 2010 Kinematics and dynamics of fault reactivation: The cosserat approach; J. Struct. Geol. 32 15-27.

Zeitler P K 1985 Cooling history of the NW Himalaya, Pakistan; Tectonics 4 127-151.

Zhang J, Ding L, Zhong D and Zhou Y 2000 Orogen-parallel extension in Himalaya: Is it the indicator of collapse or the product in process of compressive uplift? China Sci. Bull. 45 114-120.

Zhang X, Jeffrey R G and Thiercelin M 2008 Escape of fluid-driven fractures from frictional bedding interfaces: A numerical study; J. Struct. Geol. 30 478490. 